\title{
Familiarity and Competition: The Case of Mutual Funds*
}

\author{
Ariadna Dumitrescu \\ ESADE Business School and University Ramon Llull \\ Javier Gil-Bazo \\ University Pompeu Fabra and Barcelona GSE
}

First Version: March 2015

\begin{abstract}
We build a model of mutual fund competition in which a fraction of investors ("unsophisticated") exhibit a preference for familiarity. Funds differ both in their quality and their visibility: While unsophisticated investors have varying degrees of familiarity with respect to more visible funds, they avoid low-visibility funds altogether. In equilibrium, bad low-visibility funds are driven out of the market of sophisticated investors by good low-visibility funds. High-visibility funds do not engage in competition for sophisticated investors either, and choose instead, to cater to unsophisticated investors. If familiarity bias is high enough, bad funds survive competition from higher quality funds despite offering lower after-fee performance. Our model can thus shed light on the persistence of underperforming funds. But it also delivers a completely new prediction: Persistent differences in performance should be observed among more visible funds but not in the more competitive low-visibility segment of the market. Using data on US domestic equity funds, we find strong evidence supporting this prediction. While performance differences survive at least one year for the whole sample, they vanish within the year for low-visibility funds. These results are not explained by differences in persistence due to fund size or investment category. The evidence also suggests that differences in persistence are not the consequence of other forms of segmentation on the basis of investor type (retail or institutional) or the distribution channel.
\end{abstract}

JEL codes: G2; G23.

Keywords: familiarity bias; competition; mutual funds; performance persistence.

\footnotetext{
*Corresponding author: Javier Gil-Bazo. Universitat Pompeu Fabra, c/Ramon Trias Fargas 25-27, 08005 Barcelona, Spain. E-mail: javier.gil-bazo@upf.edu. Tel.: +34 93542 2718. Fax: +34 93542 1746. Ariadna Dumitrescu acknowledges the financial support of Spain's Ministry of Education (grant ECO2011-24928), Government of Catalonia (grant 2014-SGR-1079) and Banc Sabadell. Javier Gil-Bazo acknowledges the financial support of the Government of Catalonia (grant 2014-SGR-549).
} 


\section{Introduction}

Academics have spent decades teaching the benefits of portfolio diversification for risk-averse investors. Despite this advice, investors tend to concentrate their holdings in stocks of companies headquartered in their country of residence and within domestic firms, they choose those to which they are geographically, linguistically or culturally close, and even the company they work for (French and Poterba, 1991; Huberman, 2001; Grinblatt and Keloharju, 2001; Benartzi, 2001). Familiarity bias can explain this lack of diversification. Familiarity biased investors overestimate the risk of unfamiliar firms or underestimate their expected return, or both. ${ }^{1}$ Familiarity bias does not only affect the composition of investors' stock portfolios. Bailey et al. (2011) report that many mutual fund investors exhibit a propensity to select funds with headquarters close to where they live, and this bias has the strongest statistical and economic association with poor fund choices among all other behavioral biases. ${ }^{2}$ While the impact of familiarity bias on asset prices has been studied in the literature (e.g., Cao et al., 2009), its effects on the market for financial services remains unexplored. In this paper we study how familiarity bias shapes competition in the market for mutual funds, as well as the consequences for fund performance.

The main goal of our paper is to investigate whether familiarity bias can explain two closely related puzzles documented in the mutual fund industry: fee setting and performance persistence. There is abundant empirical evidence that differences in mutual fund fees do not reflect differences in before-fee performance (see, e.g., Gil-Bazo and Ruiz-Verdú, 2009). There is also much evidence that performance persists at least in the short run, and even in the long run in the case of the worst performing funds (Carhart, 1997). Both pieces of evidence contradict the central prediction of Berk and Green (2004). These authors assume that investors demand shares of all funds with expected risk-adjusted performance net of fees and other costs higher than their reservation return, which is assumed to be zero. In the presence of diseconomies of scale, flows of money into (out of) funds decrease (increase) fund performance. In equilibrium,

\footnotetext{
${ }^{1}$ An alternative explanation is that investors possess and exploit non-public information about familiar investments (Ivković and Weisbenner, 2005, Massa and Simonov, 2006). However, individuals' portfolios of local holdings do not outperform passive benchmarks by a statistically or economically significant amount (Seasholes and Zhu, 2010).

${ }^{2}$ Bailey et al. (2011) find that investors that invest in funds headquartered in the proximity of their place of residence tend to invest in funds with higher expense ratios, higher front end loads, and higher turnover, after controlling for other behavioral biases.
} 
all funds offer the same expected performance net of fees. Therefore, fees are higher for funds with higher before-fee expected performance, and differences in net performance between funds are unpredictable.

In order to achieve our goal, we build a model that captures three aspects of familiarity. First, an investor's familiarity with a mutual fund is defined by the distance between the investor and the fund. One can think of distance as geographic distance but also, and more generally, as being inversely related to the amount of exposure to information about the mutual fund due to past investment experience with the same fund or management company, amount of personal referrals, or other reasons. Second, some funds are more visible than others, making them more familiar to all investors. The idea is that while some investors are more familiar with Fidelity Investments and other investors are more familiar with Vanguard Group, most of them are more familiar with both Fidelity and Vanguard funds than with those offered by small companies, such as Merger Funds or Buffalo Funds. Third, not all investors are equally prone to familiarity bias. More financially sophisticated investors overcome lack of familiarity by investing in research and comparing funds, either because they have more at stake-they are wealthier-or because learning is less costly for them-they are more financially literate, more experienced, or better educated. ${ }^{3}$

We study a market in which actively managed funds of two different qualities compete to attract investors' money. In this market there are two types of investors: unsophisticated investors, prone to familiarity bias; and sophisticated investors. In addition to quality, funds differ in their visibility. While unsophisticated investors suffer a disutility from investing in highly visible but less familiar funds, their lack of familiarity with low-visibility funds is so high that they shun them altogether. ${ }^{4}$ Our model delivers a number of predictions. First, in equilibrium bad lowvisibility funds are driven out of the market by good low-visibility funds. Second, in equilibrium there is segmentation in that high-visibility funds cater to unsophisticated investors and refuse to compete for sophisticated investors, who invest only in good low-visibility funds. Third, if the disutility of investing in unfamiliar funds is high enough relative to performance differences,

\footnotetext{
${ }^{3}$ Bekaert et al. (2014) study the international diversification of 3 million 401(k) accounts and report that investor income, wealth, education, and financially literacy are all strongly and positively associated with international diversification.

${ }^{4}$ One may think of the disutility from investing in unfamiliar funds as the decrease in investor's perception of risk-adjusted performance for such funds.
} 
bad high-visibility funds coexist with good high-visibility funds in the unsophisticated segment of the market and offer lower after-fee expected performance. Therefore, familiarity bias can explain the puzzling survival of funds that are expected to underperform. But the model also delivers a completely new prediction: While we can expect differences in after-fee performance among high-visibility funds, we should expect no differences in after-fee performance among low-visibility funds. This is a natural consequence of segmentation: Competition is fierce in the low-visibility segment of the market, but is relaxed by familiarity bias in the high-visibility segment. To the extent that quality persists, the model predicts that observed differences in performance among the more visible funds also persist through time. In contrast, any performance differences among low visibility funds are the consequence of luck and short-lived. Finally, for intermediate levels of familiarity bias, the model yields a new prediction regarding strategic fee setting: High-visibility funds charge higher fees on average than low-visibility funds.

To test the model's predictions, we use US domestic equity mutual fund data covering the 1993-2010 period. We proxy for fund visibility using the size, age and diversity of investment categories of the fund's family. We also use advertising expenditures at the family level. Measuring both past and future performance using the four-factor model of Carhart (1997), we find strong evidence of persistent performance differences across funds over a one-year period, conditional on other observable fund characteristics. In contrast and consistently with the model's prediction, the least visible funds exhibit no persistence in performance. This is true for both underperformance and outperformance. Funds whose past performance has been in the bottom decile of the distribution in the last twelve months and which belong to the group of low-visibility funds, do not perform significantly worse than funds with median past performance. Similarly, the performance of less visible recent winners is not significantly better than that of the median fund. These results are not driven by different performance persistence for funds of different sizes or funds in different investment categories.

When past performance is measured using raw returns, we only find evidence of performance differences between the worst recent performers and the median fund for the whole sample. Again, low-visibility funds exhibit no evidence of performance persistence.

We consider and test two alternative explanations. First, while some mutual fund shares are 
available to retail investors, others can be purchased only by institutional investors. Regardless of the economic reasons why this form of product differentiation arises in the mutual fund market, one would expect institutional investors to be more sophisticated than retail investors, and thus, more responsive to differences in performance. Second, there exists evidence of large differences between funds sold directly to investors and funds sold through brokers. In particular, funds in the broker channel tend to be more expensive and underperform, even before expenses (Bergstresser et al., 2009; Christoffersen et al., 2013; Del Guercio and Reuter; 2014). As explained below, such segmentation may arise as the consequence of differences in fee sensitivity across investors, with the least fee-sensitive investors choosing to pay a mark-up for advice. To rule out the possibility that our results are simply capturing differences between retail funds and institutional funds or differences in persistence due to the distribution channel, we run a subsample analysis of persistence. Results suggest that both retail funds and institutional funds exhibit very similar levels of persistence. We do not find differences in performance persistence between directly sold and brokered funds, either.

Finally, consistently with the model prediction and intermediate levels of familiarity bias, we find that investors in low-visibility funds pay economically and statistically lower fees than investors in all other funds.

Our paper is part of a literature that tries to understand why performance differences across mutual funds persist. One possible explanation is that contrary to the assumption of Berk and Green (2004), there are no diseconomies of scale in money management. Ferreira et al. (2013) study the relationship between fund size and performance in 27 countries and find that most countries do not have decreasing returns to scale in asset management. However, they also document that performance persists even in those countries with decreasing returns to scale. Similarly, Bessler et al. (2010) show that outflows from underperforming funds alone cannot eliminate their performance disadvantage. They do find, however, that outflows from underperforming funds combined with manager replacement can cause reversals in performance. Reuter and Zitzewitz (2010) study the effect of fund flows on performance using a regression discontinuity approach and estimate diseconomies of scale of a magnitude larger than estimated in standard regression but insufficient to eliminate performance persistence. 
Therefore, empirical tests of the Berk and Green (2004) model suggest that fund flows do not eliminate performance differences. But, what stops money from flowing freely from underperforming to outperforming funds? Berk and Tonks (2007) and Glode et al. (2011) provide an answer to that question. Berk and Tonks (2007) argue that differences in the speed of learning across investors cause the composition of a fund's investor base to change with performance, since the first investors to leave or enter a fund are those who update their beliefs the fastest. As a consequence, remaining investors of a fund that has underperformed in the past have a lower flow-to-performance sensitivity, which prevents the fund's assets from shrinking should the fund continue to underperform in the future. They report evidence that funds that have performed poorly in each of the last two years are more likely to underperform in the future than funds that have performed poorly only in the last year. Glode et al. (2011) study time variation in performance persistence and find evidence that mutual fund performance persistence is strongest following periods of high market returns and vanishes after periods of low market returns. The authors argue that differences in performance persistence across market conditions may be explained by time-varying differences in the participation of unsophisticated investors in the mutual fund market, with a higher fraction of unsophisticated investors leading to larger deviation from the no-predictability equilibrium. Like Berk and Tonks (2007) and Glode et al. (2011), we also propose lack of investor sophistication as the reason why fund performance persists. Unlike those papers, we try to unveil the specific bias that makes unsophisticated investors less sensitive to differences in performance in the first place. We also provide an explanation for why competition for sophisticated investors is not sufficient to equate performance across funds.

A challenge of any model of mutual fund competition is to explain why low-quality funds are not priced out of the market by high-quality funds in the absence of diseconomies of scale. In a duopoly model of vertical differentiation, Metrick and Zeckhauser (1998) show that when investors have different subjective valuations of fund quality, the high-quality fund will sell at a higher price to the most quality-sensitive investors, while the bad-quality fund will survive by selling at a low price to less quality-sensitive investors. Moreover, if a fraction of all investors are uncertain about fund quality, it is possible to have a pooling equilibrium in which lowquality funds set the same price as high-quality funds and sell only to uninformed investors. 
Nanda et al. (2000) study a model in which mutual fund managers compete to attract investors with low liquidity needs by offering them lower management fees and imposing exit fees. In equilibrium, more skilled fund managers outbid less skilled managers, who become liquidity providers. Gil-Bazo and Ruiz-Verdú (2008) study a market with multiple mutual funds and identical investors in which a fund manager's ability is known only by the manager herself. In this setup, only pooling equilibria are possible. However, under the assumption that a fraction of investors are not responsive to the information contained in mutual fund fees, the authors show the existence of a separating equilibrium in which high-quality funds signal their quality through low fees and low-quality funds must cater to price-inelastic investors to whom they charge high fees. Gennaioli et al. (2015) model a duopoly market in which investors wish to invest in risky assets only through a trusted money manager. Half of the investors trust one fund more than the other, who, in turn, is trusted more by the other half. More trust in the manager reduces investor's disutility from taking risk. In equilibrium managers split the market with each investor delegating his portfolio to his most trusted manager. Equilibrium fees are proportional to expected returns, which provides managers with incentives to direct their investors towards assets with higher perceived expected returns.

Like the models cited above, ours departs from the perfectly competitive equilibrium and explains why strategically-set fees may not offset differences in quality. The novelty of our model is that we introduce a new dimension along which mutual funds differ: familiarity to investors. Moreover, by allowing for an extreme level of familiarity that depends only on the characteristics of funds but not on those of investors, low visibility, we can empirically distinguish between our model and other models that generate persistent differences in fund performance using the available mutual fund data. In this sense, our model is more closely related to the work of Sun (2014), who studies a market in which segmentation between directly sold funds and brokered funds, which are bundled with advice, arises as the consequence of differences in investors' fee sensitivity.

The results of our paper have important implications. First, the empirical results combined with our theory suggest that the presence of familiarity biased investors in the mutual fund market, far from being negligible, is large enough to generate persistent differences in fund 
performance. With over USD15 trillion of US investors' money invested in mutual funds at yearend 2013, USD6.5 trillion of which are held through defined contribution plans and individual retirement accounts, the consequences of persistent differences in performance for investor wealth are considerable. ${ }^{5}$ Our results suggest that such differences would be attenuated by reducing investors' familiarity bias. Second, the presence of sophisticated investors in the market is not a sufficiently strong incentive for funds to set fees that offset differences in before-fee performance. Third, entry of new competitors is not likely to alleviate this situation in the short term due to lack of familiarity of investors with new fund families.

The rest of the paper is organized as follows. In section 2 , we present the theoretical framework of our analysis. In section 3, we describe the data set. In section 4 we present our main empirical results. Section 5 explores two alternative hypotheses. Section 6 investigates differences in fees. Finally, section 7 concludes. All proofs can be found in the Appendix.

\section{The model}

Actively managed funds compete for investors' money. We consider two continuums of investors: sophisticated investors, with density $\lambda_{S}$; and unsophisticated investors, with density $\lambda_{U}$. Unsophisticated investors are prone to familiarity bias: they derive a disutility from investing in less familiar funds. As an alternative to active funds, investors can choose to invest with an index fund offering a zero expected risk-adjusted return and charging a zero fee. Active funds differ from each other in two dimensions: quality and visibility. More specificallly, we assume that there are four active funds and each one of the four funds is different from the other three in terms of either quality $(\theta)$ or visibility $(v)$, or both, with $\theta \in\{G, B\}$ and $v \in\{H, L\}$, where $G$ and $B$ denote high and low quality, respectively, and $H$ and $L$ denote high and low visibility, respectively. A fund's type is common knowledge. We denote the expected risk-adjusted performance of high-quality (henceforth good) and low-quality (henceforth bad) funds by $R_{G}$ and $R_{B}$, respectively, with $R_{G}>R_{B}$. For simplicity, we refer to expected risk-adjusted performance as return. When choosing among high-visibility funds, investors exhibit a preference for more

\footnotetext{
${ }^{5}$ Data from the Investment Company Institute's 2014 Investment Company Fact Book, http://www.icifactbook.org.
} 
familiar funds. However, the disutility of investing in low-visibility funds to unsophisticated investors is so large that no unsophisticated investor ever finds it optimal to invest in them. This means that unsophisticated investors choosing to invest in active funds are restricted to the two high-visibility funds.

To model unsophisticated investors' preference for more familiar funds, we build on Hotelling's (1929) model of horizontal differentiation. Unsophisticated investors are uniformly distributed along a familiarity line of length $\lambda_{U}$ and the two high-visibility funds are located at the extremes of the line. The good, high-visibility fund is located at $x=0$. The bad, high-visibility fund is located at $x=\lambda_{U}$. We assume that the disutility of investing in a less familiar fund is a quadratic function of the distance between the investor and the fund. ${ }^{6}$ In particular, an investor living at $x$ suffers a disutility $k x^{2}$ from investing in the good fund and a disutility of $k\left(\lambda_{U}-x\right)^{2}$ from investing in the bad fund.

\subsection{The investor's problem}

Each investor is endowed with one dollar, and pays a fee, $f$, for investing with an active mutual fund. Sophisticated investors derive a utility equal to $U_{\theta v}^{S}=R_{\theta}-f_{\theta v}$, for investing in the active mutual fund of quality $\theta$ and visibility $v$. The unsophisticated investor $i$ derives a utility equal to $U_{i, \theta v}^{U}=R_{\theta}-f_{\theta v}-k d_{i, \theta v}^{2}$, where $d_{i, \theta v}$ denotes the distance between the investor and the fund. Utility from investing with the index fund is zero. An investor decides to invest with fund $\theta v$ as long as the utility from investing with that fund is both positive and higher than the utility from investing with any other active fund.

The demand of the sophisticated investors is split equally across all active funds offering the highest positive net-of-fee return and is zero for all the other funds.

The demand of the unshophisticated investors for the low-visibility funds is zero by assumption. Each unsophisticated investor chooses to invest in the high-visibility fund offering the highest utility given the fund's return, fee, and the distance between the fund and the investor, as long as this utility is positive, otherwise she invests in the index fund. In case that both funds offer the same positive utility, her wealth is split equally between them.

\footnotetext{
${ }^{6}$ Our results are qualitatively the same if we assume a linear function for disutility.
} 


\subsection{The manager's problem}

Fund managers choose the fees that maximize their profits given investors' demand functions and the other managers' strategies. Without loss of generality, we assume that the marginal cost to the manager of operating the fund is zero. Therefore, the manager's problem becomes:

$$
\max _{f_{\theta v}} \Pi_{\theta v}=f_{\theta v}\left(q_{U, \theta v}+q_{S, \theta v}\right)
$$

where $q_{U, \theta v}, q_{S, \theta v}$ denote the total demand for the fund from unsophisticated and sophisticated investors, respectively.

\subsection{Equilibrium}

The two high-visibility funds, $G H$ and $B H$, are differentiated products for unsophisticated investors because of their location. The two low-visibility funds, $G L$ and $B L$, on the other hand, are not differentiated in that they are perfect substitutes in the sophisticated investors' utility function: All sophisticated investors value net returns equally and invest in the fund that gives them the highest net return. The low-visibility funds engage in Bertrand-like competition. Since the returns are such that $R_{G}>R_{B}$, the $G L$ fund can drive the $B L$ fund out of the market simply by undercutting the fee. The $B L$ fund cannot set a fee, $f_{B L}$, lower than zero. By setting a fee such that $f_{G L}<R_{G}-R_{B} \equiv \Delta$, the $G L$ fund gains all the market of sophisticated investors and the $B L$ fund does not operate in the market.

Lemma 1 In equilibrium, no investors choose to invest in the bad low-visibility (BL) fund.

In next lemma, we show that sophisticated investors do not invest in high-visibility funds, either.

Lemma 2 In equilibrium, high-visibility funds cater to unsophisticated investors and low-visibility funds cater to sophisticated investors.

To see how this form of segmentation arises in equilibrium, assume that high-visibility funds decide to compete against low-visibility funds for sophisticated investors. For the same reasons 
that $B L$ is driven out of the market, $B H$ does not attract any sophisticated investors. If the two good funds, $G H$ and $G L$, engage in price competition, since both funds offer the same return $R_{G}$, each has an incentive to undercut its fee until the fee equals zero, i.e., $f_{G L}=f_{G H}=0$. At that fee, both $G H$ and $G L$ make zero profits. However, $G H$ can always charge an arbitrarily small but positive fee and make positive profits by operating only with unsophisticated investors. More specifically, it is sufficient for the $G H$ fund to charge a fee lower than $\Delta \equiv R_{G}-R_{B}$ to dominate the $B H$ fund for investors sufficiently familiar with $G H$ regardless of the fee charged by the $B H$ fund. This ensures that those investors that are closest to $G H$ are willing to invest in it, and therefore the $G H$ makes a positive profit.

The two high-visibility funds, $G H$ and $B H$, compete only against each other for unsophisticated investors. When all unsophisticated investors purchase low-visibility funds, the market is covered. When some unsophisticated investors decide to invest in the index fund, the market is not covered and the two highly visible funds act as local monopolies. Depending on the model parameters, we have three possible situations. First, the market is covered and all unsophisticated investors invest in the $G H$ fund. This happens when the disutility of investing in unfamiliar funds, which depends on $k$, is small relative to the difference in returns, $\Delta$, and given the distance between both funds $\lambda_{U}$. Second, the market is covered and the two high-visibility funds share the market of unsophisticated investors. This happens for an intermediate value of $k$, given the other parameters. Third, when $k$ is very high, the market is not covered: Funds act as local monopolies and set fees accordingly. Consequently, familiarity bias allows both good and bad funds to coexist in equilibrium as long as differential performance is not very large relative to the utility cost of investing in unfamiliar funds. These results are presented in the following Proposition: 
Proposition 1 In equilibrium, the fees charged by the funds are the following

$$
\begin{aligned}
& f_{G H}^{*}=\left\{\begin{array}{clc}
\Delta-k\left(\lambda_{U}\right)^{2} & \text { if } & k \leq k_{0}, \\
k\left(\lambda_{U}\right)^{2}+\frac{1}{3} \Delta & \text { if } & k_{0}<k<k_{1}, \\
\frac{2}{3} R_{G} & \text { if } & k \geq k_{1},
\end{array}\right. \\
& f_{B H}^{*}=\left\{\begin{array}{ccc}
0 & \text { if } & k \leq k_{0}, \\
k\left(\lambda_{U}\right)^{2}-\frac{1}{3} \Delta & \text { if } & k_{0}<k<k_{1}, \\
\frac{2}{3} R_{B} & \text { if } & k \geq k_{1} .
\end{array}\right. \\
& f_{G L}^{*}=\left\{\begin{array}{cc}
\frac{\lambda_{U}}{\lambda_{S}+\lambda_{U}}\left(\Delta-k \lambda_{U}^{2}\right)-\varepsilon & \text { if } k \leq k_{0}, \\
\min \left\{\Delta, f^{*}\right\}-\varepsilon \quad \text { if } k \in\left(k_{0}, k_{1}\right), \\
\min \left\{\Delta, f^{* *}\right\}-\varepsilon & \text { if } k \geq k_{1}
\end{array}\right. \\
& f_{B L}^{*}=0,
\end{aligned}
$$

and the quantities invested in each fund are

$$
\begin{aligned}
q_{S, G L}^{*} & =\lambda_{S}, \\
q_{S, G H}^{*} & =q_{S, B H}^{*}=q_{S, B L}^{*}=0, \\
q_{U, G L}^{*} & =q_{U, B L}^{*}=0, \\
q_{U, G H}^{*} & =\left\{\begin{array}{ccc}
\lambda_{U} & \text { if } & k \leq k_{0}, \\
\frac{1}{2 k \lambda_{U}}\left(k\left(\lambda_{U}\right)^{2}+\frac{1}{3} \Delta\right) & \text { if } & k_{0}<k<k_{1}, \\
\sqrt{\frac{R_{G}}{3 k}} & \text { if } & k \geq k_{1}, \\
0 & \text { if } & k \leq k_{0},
\end{array}\right. \\
q_{U, B H}^{*} & =\left\{\begin{array}{clc}
\frac{1}{2 k \lambda_{U}}\left(k\left(\lambda_{U}\right)^{2}-\frac{1}{3} \Delta\right) & \text { if } & k_{0}<k<k_{1}, \\
\sqrt{\frac{R_{B}}{3 k}} & \text { if } & k \geq k_{1} .
\end{array}\right.
\end{aligned}
$$

where $\varepsilon$ is strictly positive and arbitrarily small, and the definitions of $f^{*}, f^{* *}, k_{0}$ and $k_{1}$ are provided in the Appendix.

In the cases in which the $B H$ fund survives, i.e., when $k>k_{0}$, it charges a lower fee than the $G H$ fund. However, the difference in fees between both funds equals $\frac{2}{3} \Delta$, which is not enough 
to fully offset the difference in before-fee performance, $\Delta$. Therefore, when the bad visible fund survives in the market, it does so despite offering lower net performance than the good visible fund. In other words, in equilibrium, investors expect differences in performance between highly visible funds. Notice that our model is static. However, since there is no asymmetric information and therefore, no role for learning about performance, a dynamic model built as a succession of static models would yield an identical outcome provided that pre-fee performance does not change over time. This observation helps understand why differences in net performance can persist.

Although we have characterized three different cases, we believe that the case in which only the $G H$ fund serves unsophisticated investors is not empirically plausible, as it would imply that there are no differences in before-fee performance between actively managed funds. Therefore, in next section, we rule out the first case and test the model's prediction for the other two cases: Persistent differences in performance should be observed among high-visibility funds but not among low-visibility funds, as Bertrand-like competition in the latter segment of the market ensures homogeneity in quality and fees.

In order to ensure that the $G H$ fund does not want to deviate from the equilibrium with segmentation, the $G L$ fund sets a lower fee than that charged by $G H$ so that the profit obtained by $G H$ from serving only unsophisticated investors is higher than the profit obtained by lowering the fee in order to serve also the entire market of sophisticated investors. Further, for intermediate values of $k$, i.e., when $k_{0}<k<k_{1}$, the fee charged by $G L$ is lower than the average fee charged by high-visibility funds. This relationship is contained in the following corollary:

Corollary 1 In equilibrium, for $k_{0}<k<k_{1}$, the average fee of high-visibility funds is higher than the fee of the low-visibility fund $\frac{1}{2}\left(f_{G H}+f_{B H}\right)>f_{G L}$.

Although we test for differences in fees in Section 6, since this is not an unambiguous prediction of the model, most of of our empirical analysis focuses on testing for differences in persistence between high- and low-visibility funds. 


\section{Data}

Our main source of data is the CRSP Survivor-Bias-Free US Mutual Fund Database. Since some of the variables employed in the analysis are available only since the early 1990s, we restrict our attention to the 1993-2010 period. We exclude index, non-domestic, non-diversified, and non-equity funds. ${ }^{7}$ We aggregate monthly data for different share classes at the fund level. In particular, we compute fund total net assets as the sum of assets of all share classes of the same portfolio, fund age as the number of years since inception of the oldest class, and all other variables (return, expense ratio, 12b-1 fee, front-end and back-end loads) as asset-weighted averages of those variables at the class level. We also compute family age and family assets as the age of the oldest fund in the family and the sum of assets of all funds in the family, respectively. Funds and families are identified using CRSP's crsp_portno and mgmt_cd variables, respectively. When those variables are not available, we use fund name and management company name, instead. To mitigate the effect of documented biases in the CRSP database, we exclude all fund-month observations with total net assets below $\$ 15$ million and age less than three years (Elton et al., 2011; Evans, 2010). Also, we winsorize expense ratios, $12 \mathrm{~b}-1$ fees, and turnover at $1 \%$ of each tail each month before aggregating class data at the portfolio level.

Throughout the paper, we evaluate mutual fund performance using Carhart's (1997) fourfactor model:

$$
r_{i t}=\alpha_{i}+\beta_{r m r f, i} r m r f_{t}+\beta_{s m b, i} s m b_{t}+\beta_{h m l, i} h m l_{t}+\beta_{p r 1 y, i} p r 1 y_{t}+\varepsilon_{i t}
$$

where $r_{i t}$ is fund $i$ 's return in month $t$ in excess of the 30-day risk-free interest rate, as proxied by Ibbotson's one-month Treasury bill rate, and $r m r f_{t}, s m b_{t}$ and $h m l_{t}$ denote the return on portfolios that proxy for the market, size, and book-to-market risk factors, respectively. The term $\operatorname{pr} 1 y_{t}$ is the return difference between stocks with high and low returns in the previous

\footnotetext{
${ }^{7}$ To identify US domestic equity funds, we use the information in CRSP on investment category as follows. For years in which the only objective code available is Wiesenberger's (wbrger_obj_cd), we consider as US domestic equity those funds with the codes: G; G-I; I-G; MCG; GCI; LTG; MCG; SCG; and IEQ. For years 1993-1999, we use the si_obj_cd codes: AGG; GMC; GRI; GRO; ING; SCG. For years 2000-2010, we use the lipper_class_name codes: LCVE; MLVE; EI; EIEI; LCCE; MLCE; LCGE; MLGE; MCVE; MCCE; MCGE; SCVE; SCCE; and SCGE. Index funds are identified by the CRSP's index_fund_flag variable when available and by portfolio name otherwise.
} 
year and is included to account for passive momentum strategies. We obtain the time series of interest rates, the Fama-French factors, and momentum from Kenneth French's website.

To estimate fund $i$ 's risk-adjusted performance in month $t$, we first regress the fund's excess return on the three Fama-French factors and momentum over the previous three years. If less than 36 monthly observations of previous data are available, we require at least 30 observations. We then compute an estimate of fund $i$ 's alpha in month $t, \hat{\alpha}_{i t}$, as the difference between the fund's excess return in month $t$ and the dot product of the vectors of estimated betas and factor realizations in that month.

We are interested in testing whether past performance predicts future performance over multi-period horizons. To compute risk-adjusted performance over the prior $h$ months in month $t$, which we denote by $\hat{\alpha}_{i, t-h: t-1}$, we sum monthly estimated alphas from months $t-h$ to month $t-1$. Future performance, denoted by $\hat{\alpha}_{i, t: t+m}$, is computed as the sum of monthly alphas from months $t$ to month $t+m$. Throughout the paper, we will focus on annual performance, so we set $h=12$ and $m=11$.

We compute flows of money to mutual funds from monthly data on assets under management and returns. In particular, monthly dollar flows in month $t$ are computed as $T N A_{t}-T N A_{t-1}(1+$ $r_{t}$ ), where TNA and $r$ denote the fund's total net assets and net return, respectively. Once we have computed monthly dollar flows, we compute annual flows by adding dollar flows over the year. In our regressions, we use annual relative flows defined as total annual flows divided by total net assets at the end of the previous year. Relative flows are also winsorized at $1 \%$ of each tail.

The final dataset contains information on an average number of 1,251 funds and 327 fund families per month. Panels A and B of Table 1 contain summary statistics of fund characteristics and performance for the 1993-2000 and 2001-2010 sample periods, respectively.

We use the following proxies for fund visibility:

1. Number of different investment categories in which the family offers mutual funds;

2. Family size, defined as total family assets;

3. Family age, computed as the age of the oldest fund in the family. 
These variables have been previously proposed by Huang et al. (2007) as proxies for investor participation costs. Low values of these variables characterize less visible funds.

For each one of these proxies, we create two dummy variables, denoted by $L O$ and $H I$, which equal one if fund $i$ belongs to the bottom and top quartiles of the variable's distribution in the month prior to the evaluation period, respectively.

In addition to the three variables on fund visibility described above, we also use advertising as a proxy for visibility. More specifically, we obtain data on advertising expenditures at the family level from Kantar Media, which tracks advertising activity in a large variety of media including magazines, newspapers, television, internet, and radio. We are able to collect information on family advertising for about $18 \%$ of all fund-month observations in the 1995-2009 period. For each family and month, we compute the average advertising expenditure over the previous 12 months. For this variable, we define the $H I$ subsample as that containing funds in the top quartile of the month's distribution. It should be noted, however, that this subsample only has 822 fund-month observations, so results for this subsample should be taken with caution. Importantly, we set $L O$ equal to one if the fund's family is not contained in the advertising database for that month.

Table 2 compares funds in the $L O$ and $H I$ subsamples on the basis of selected fund characteristics. Less visible funds according to the number of investment categories, family size and family age, are substantially smaller; they charge lower front-end loads, $12 \mathrm{~b}-1$ fees, and back-end loads, but higher management fees; and they exhibit better risk-adjusted performance although the difference in performance is not statistically significant. When we use family advertising to proxy for fund visibility, we still find that funds in the $L O$ subsample are smaller and charge higher management fees. However, these funds also charge higher back-end loads and exhibit worse performance. 


\section{Fund visibility and performance persistence}

\subsection{Methodology}

To estimate persistence in mutual fund performance, the literature has employed two main alternative methodologies. The more traditional approach consists of sorting funds at the beginning of each evaluation period on the basis of their past performance. Funds are then grouped in quantile portfolios and portfolio returns are computed over the evaluation period. Finally, riskadjusted performance is measured using the time series of quantile portfolio returns. Failure to find differences in risk-adjusted performance across portfolios is interpreted as lack of persistence in mutual fund performance. This approach has been employed to study performance persistence by Hendricks et al. (1993), Gruber (1996) and Carhart (1997), and Elton et al. (2011), among others. The portfolio-based approach serves two purposes: It tests for persistence in performance and it quantifies the value of investing on the basis of past performance. However, the approach suffers from the same problem as all nonparametric methods, i.e., it requires a large amount of data in multivariate settings. ${ }^{8}$

As an alternative, the regression-based approach consists of regressing future performance on past performance and then testing whether the regression coefficient is zero. This approach has been used by Busse et al. (2010), Elton et al. (2011), and Ferreira et al. (2013). By imposing a parametric specification on the functional relation between future performance and past performance and other variables, we can control for the effect of fund characteristics on performance and allow for persistence to vary with those characteristics with less stringent data requirements. Because we are interested in testing whether the degree of performance persistence changes with fund visibility while controlling for a number of other variables, we choose the regression approach.

We start by regressing future performance on past performance. Then, we allow for possible

\footnotetext{
${ }^{8}$ Suppose we wished to test for performance persistence while controlling for the effect of fund size on future performance. We could sort funds on both past performance and size, allocate funds to the resulting performance-size bins, and then compare portfolios that are neutral to size but correspond to different quantiles of past performance. Also, if our goal were to test whether performance persistence changes with size, we could compare portfolios across both past performance and size bins. The problem is that the number of bins grows geometrically with the number of fund characteristics whose association with performance we wish to study.
} 
non-linearities and regress future performance on dummy variables corresponding to different deciles of past performance.

\section{$4.2 \quad$ Results}

To evaluate the prevalence of performance persistence in the entire sample, we estimate by pooled OLS the regression equation:

$$
\hat{\alpha}_{i, t: t+11}=\delta_{0, t}+\delta_{1} \hat{\alpha}_{i, t-12: t-1}+\Delta X_{i, t-1}^{\prime}+\xi_{i, t: t+11}
$$

where each observation corresponds to one fund-month pair, $X$ is a row vector of control variables, and $\varepsilon$ denotes a generic error term. Control variables include: fund size in month $t-1$, defined as the natural logarithm of the fund's assets; relative flows of money into the fund during the year ending in month $t-1$; fund age, defined as the natural logarithm of the fund's age in months; family size in month $t-1$, defined as the natural logarithm of the assets under management of the management company to which the fund belongs; and family age, defined as the natural logarithm of the management company's age in months. We also control for the fund's maximum front-end load, maximum back-end load, expense-ratio, and turnover ratio. Since values of fees and turnover are reported for the entire fiscal year, their value in month $t-1$ is not strictly lagged with respect to future performance unless month $t-1$ is the last month of the fiscal year. To ensure that those variables are known before month $t$, we use a lag of 12 months for them. Like in the rest of the regressions presented in this paper, we allow for time fixed effects and compute standard errors clustered by both fund and time to account for serial and cross-sectional correlation of residuals, respectively.

The first column in Table 3 reports estimation results for equation (2). The coefficient on past performance is positive and statistically significant at the $1 \%$ level, which suggests that past performance persists for periods of at least one year, consistently with previous studies. Both fund size and lagged flows are negatively and significantly associated with performance. Funds belonging to larger management companies are associated with better performance, as documented by Chen et al. (2004). Finally, the fund's back-end load, expense ratio, and turnover 
ratio are negatively related to performance, although the coefficient for turnover ratio is only marginally statistically significant. In sum, these results are consistent with a large body of empirical evidence that future US equity fund performance is predictable from the cross-section of past performance and other fund characteristics.

We then interact the dummy variables $L O$ and $H I$ obtained according to the four proxies of fund visibility with past performance, and estimate the regression equation:

$$
\begin{aligned}
\hat{\alpha}_{i, t: t+11}=\theta_{0, t}+\theta_{1} \hat{\alpha}_{i, t-12: t-1}+ & \theta_{2} \hat{\alpha}_{i, t-12: t-1} L O_{i, t-1}+\theta_{3} \hat{\alpha}_{i, t-12: t-1} H I_{i, t-1}+ \\
& +\theta_{4} L O_{i, t-1}+\theta_{5} H I_{i, t-1}+\Theta X_{i, t-1}^{\prime}+v_{i, t: t+11},
\end{aligned}
$$

where we also include the two dummy variables to allow for the possibility of different means for each group of funds. We are mainly interested in the coefficients $\theta_{2}$ and $\theta_{3}$. Columns 2-5 of Table 3 show the estimation results for each of the four proxies. The coefficients of the interaction of performance with the $L O$ dummy $\left(\theta_{2}\right)$ are negative in all four cases and statistically significant at the $1 \%$ level (family age), $5 \%$ level (number of investment categories and family advertising), and $10 \%$ level (family size). Estimation results, therefore, suggest that differences in performance are shorter-lived for the least visible funds than for the rest of funds. Moreover, in contrast to other funds, the least visible funds exhibit no performance persistence: The regression coefficient on past performance for these funds, $\theta_{1}+\theta_{2}$, is not statistically significant for any of the proxies (unreported). We do not find differences in performance persistence between highly visible funds and the rest of funds, which suggests that the relation between visibility and persistence is not linear.

An obvious concern about these results is the possibility that they capture differences in persistence across funds due to other fund characteristics. As mentioned in the introduction, Elton et al. (2011) test the hypothesis that there should be less performance persistence among larger funds, for which diseconomies of scale are more likely to be important, although they do not find support for that hypothesis. Also, funds in different investment categories may exhibit different degrees of performance persistence due to differences in the nature of the markets in which they operate. To control for both possibilities, we include interactions of performance 
with fund size and with dummies for investment categories. The estimation results are reported in Table 4. The coefficients on the interactions of size with performance are negative, but not statistically significant except in column 3 (Family Size), where it is only marginally significant. The fact that the interaction of performance with size is not significant provides further support to the finding of Elton et al. (2011) that performance persistence does not decline with fund size. Further, all signs for the interactions of past performance with the $L O$ dummies are negative and the coefficients are statistically significant at the $1 \%$ level in all cases except for the family advertising proxy $(5 \%)$.

In sum, the results of Table 3 and 4 are strongly indicative that there exist differences in performance persistence associated with fund visibility and that such differences in persistence cannot be explained by differences in fund size or differences in investment categories.

Low persistence among certain types of funds may be the consequence of either recent underperformers improving their performance or recent outperformers delivering lower performance, or both. To disentangle the reason why less visible funds exhibit less persistent differences in performance, we estimate the regression equation:

$$
\begin{aligned}
\hat{\alpha}_{i, t: t+11}= & \delta_{0, t}+\sum_{n} \delta_{1, n} d e c \_n n_{i, t-1} \\
& +\sum_{n} \delta_{2, n} d e c \_n_{i, t-1} L O_{i, t-1}+\sum_{n} \delta_{3, n} d e c_{-} n_{i, t-1} H I_{i, t-1} \\
& +\delta_{4} L O_{i, t-1}+\delta_{5} H I_{i, t-1}+\Delta X_{i, t-1}^{\prime}+\nu_{i, t: t+11},
\end{aligned}
$$

where $d e c_{-} n_{i, t-1}$ is a dummy variable that equals one if fund $i$ 's performance is in the $n$-th decile of all funds' alphas over the prior twelve months. We omit the dummy variables corresponding to the four central performance deciles, i.e., we only include in the regression the dummy variables corresponding to the top three and bottom three performance deciles.

Once equation (4) has been estimated, we test whether the underperformance of funds in the $L O$ subsample is shorter-lived than that of otherwise similar recent underperformers. More specifically, $\delta_{1,1}+\delta_{2,1}$ captures the difference in expected performance between a $L O$ fund whose past performance belongs to the first decile of the distribution and an otherwise identical $L O$-fund with past performance in the central deciles. The coefficient $\delta_{1,1}$ captures the 
difference in expected performance between a fund outside the $L O$ and $H I$ subsamples whose past performance belongs to the first decile of the distribution and an otherwise identical fund with performance in the central deciles. Therefore, a positive value of $\delta_{2,1}$ implies that the performance of underperforming $L O$-funds converges faster to the median fund's performance than the performance of funds that do not belong to the $L O$ or $H I$ subsamples. Analogously, a negative value of $\delta_{2,10}$ indicates that the performance of outperperforming $L O$-funds converges faster to the median fund's performance than the performance of funds that do not belong to the $L O$ or $H I$ subsamples. Similarly, $\delta_{3,1}\left(\delta_{3,10}\right)$ is positive (negative) if $H I$-funds in the bottom (top) performance decile converges to that of the median fund faster than that of funds with $L O=H I=0$.

Column 1 of Table 5 reports estimation results when no interactions with $L O$ and $H I$ are included in the regression equation. The estimated coefficients on the three bottom (top) performance decile dummies are negative (positive) and statistically significant at any significance level. Future performance also appears to increase monotonically with past performance. Differences in performance across deciles are economically significant: Recent top performers outperform otherwise identical funds in the bottom decile by 180 basis points per year.

In columns 2-4 we report estimation results when interactions with $L O$ and $H I$ are included and investor sophistication is determined according to the number of investment categories in which the family offers funds, family size, and family age. The coefficient on the interaction between the bottom decile dummy and $L O, \delta_{2,1}$, is positive and statistically significant, suggesting that low-visibility underperforming funds exhibit better relative performance than otherwise similar underperforming funds. In contrast, none of the coefficients on the interaction of the bottom decile dummy and $H I$ is statistically significant. When we use family advertising to define fund visibility, we find no difference in performance persistence for underperforming funds in the low-visibility subsamples and otherwise similar funds. As mentioned above, when the fund's family is not contained in the advertising database for that month, we assume that the advertising expenditures are zero for that family and set $L O$ equal to one. This approach may overestimate the number of funds in the low-visibility subsample.

We then ask whether good performance reverts faster for low-visibility funds. The answer is 
yes: The coefficients on the interaction terms between $L O$ and the top decile dummy, $\delta_{2,10}$, are negative and significant for all four proxies of low visibility. None of the interaction terms with the top decile dummy is significant for high-visibility funds.

Therefore, the results of Table 5 indicate that the lower performance persistence documented in Tables 3 and 4 for low-visibility funds is due to these funds' performance reverting fast to median performance.

\subsection{Ranking on returns}

So far, we have used Carhart's four-factor model to measure fund performance both in the ranking period and in the evaluation period. There is no consensus in the literature on mutual fund performance persistence as to whether the researcher should employ the same model to rank funds and measure subsequent performance. On the one hand, failing to control for a specific positively-priced risk factor in the ranking period contaminates the ranking: Top decile portfolios contain both funds with true high alpha and funds with a high beta with respect to the omitted risk factor. On the other hand, using the same asset pricing model to sort and estimate performance also picks up the model bias, as pointed out by Carhart (1997). While the former approach may bias results against finding persistence, the latter may bias results in favor of finding persistence.

To examine whether our conclusions are robust to ranking funds on past returns, we repeat the tests of Table 5 using fund returns measured over the last 12 months to define decile dummies. Table 6 reports the results. The estimated coefficients on the decile dummies when no interactions are included (column 1) are similar to those of Table 5 for the bottom decile dummies. However, the coefficients on the top decile dummies are much lower in absolute value than those obtained when past performance is measured using the four-factor model. In fact, there is no evidence of persistence in outperformance when funds are ranked on past returns. Therefore, funds in the top deciles of past performance are not separated from mid-ranked funds in terms of their subsequent performance.

Consistently with the results of Table 5, the underperformance of bottom-ranked funds in the low-visibility subsample tends to vanish in the subsequent year if the low-visibility subsample 
is defined according to the number of investment categories, family size, and family age, but not advertising expenditures. However, the coefficients on the interaction of $L O$ with the top decile dummies are not statistically significant. Also, with one exception, none of the coefficients on the interaction of $H I$ with the top decile dummies is statistically significant.

The results of Table 6 suggest that lack of persistence in the underperformance of the least visible funds appears to be robust to model bias. We do not find, however, that more visible funds exhibit less persistence following good performance, simply because there is no evidence of persistence in good performance when funds are ranked according to past fund returns.

\section{Alternative hypotheses}

So far, our results suggest that differences in annual performance do not survive another year among low visibility funds. While this finding is consistent with segmentation of the mutual fund market on the basis of investors' proneness to familiarity bias, in this section we consider and test two alternative explanations. First, while some mutual fund shares are available to retail investors, others can be purchased only by institutional investors. Since institutional investors are likely to be more sophisticated than retail investors, one would expect them to respond more quickly to differences in after-fee performance, which could make differences in persistence last shorter than in the retail segment of the market.

Second, as mentioned in the introduction there exists evidence of economically and significant differences between funds sold directly to investors and funds sold through brokers in terms of their fees and performance. Sun (2014) shows how that this form of segmentation can be the outcome of mutual fund competition when investors differ in their sensitivity to fees. Although Sun (2014) does not consider differences in performance, since more price sensitive investors self-select into the direct channel, competition in this channel is more intense and persistence in performance differences should be less likely than in the direct distribution channel.

To rule out the possibility that our results are simply capturing differences in persistence due to the type of fund or due to the distribution channel, we identify retail funds, institutional funds, brokered funds, and directly sold funds, and run the regression below for each of the four 
subsamples:

$$
\hat{\alpha}_{i, t: t+11}=\delta_{0, t}+\sum_{n} \delta_{1, n} d e c \_n_{i, t-1}+\Delta X_{i, t-1}^{\prime}+\nu_{i, t: t+11},
$$

where $d e c \_n_{i, t-1}$ has the same definition as above and we omit the dummy variables corresponding to the four central performance deciles.

To identify institutional share classes, we use the CRSP identifiers when available, and the fund's or class' name otherwise. Institutional funds are then defined as those offering share classes that account for more than $50 \%$ of the fund's total assets, while retail funds are those with less than 50\% of their assets in institutional classes. Following Sun (2014), we assume that share classes charging a front-end load, or a back-end load, or a $12 \mathrm{~b}-1$ fee higher than 25 basis points, are distributed through brokers. Brokered funds are then defined as those in which brokered share classes account for more than $50 \%$ of the fund's assets, with the rest of funds defined as directly sold. ${ }^{9}$

Estimation results for each one of the four subsamples are reported in Table 7 . To facilitate interpretation of results, we also display the coefficient estimates and standard errors for the whole sample in column 1 . The coefficients on past performance decile dummies for retail funds (column 2) are very similar to those in the first column. They are also quite similar to those for institutional funds (column 3), suggesting that both types of funds exhibit similar levels of performance persistence. We also find similar coefficients, and therefore similar levels of persistence among brokered funds (column 4) and directly-sold funds (column 5).

Therefore the results of Table 7 suggest that the differences in performance persistence documented in the previous section do not simply capture other forms of segmentation due to either differences between retail and institutional investors or to the distribution channel. Instead, our results unveil a different form of segmentation that has not been previously documented in the literature, and that is related to differences in investors' predisposition to invest with familiar funds.

\footnotetext{
${ }^{9}$ Our results are robust to alternative definitions of both institutional and brokered funds based on 25-75\% thresholds. Results are available from the authors.
} 


\section{$6 \quad$ Fund visibility and mutual fund fees}

To provide further support to the model, in this section we focus on the model's prediction regarding fee differences. As stated in Corollary 1, when the the disutility of investing in visible funds is neither too low nor too high, the average fees of highly visible funds exceed those of low visibility funds. In Tables 8 and 9, we test this prediction. This exercise is of course a joint test of our model and the hypotheses that the intensity of familiarity bias $(k)$ takes an intermediate value.

As mentioned above, fee data are typically valid for the entire fiscal year. Therefore, we choose an annual frequency for our regressions. In particular, we define total annual fee as the sum of the expense ratio and annualized front-end and back-end loads, assuming a 1-year and a 5-year holding period, respectively. We then run pooled OLS regressions for all fund-year observations of total fees on our low- and high-visibility dummies, potential fee determinants lagged one year, and past performance, defined as the (annualized) intercept from regression (1).

Inspection of Tables 8 and 9 suggests that fees are statistically and economically significantly lower for low-visibility funds using the number of investment categories of the management company, its age, and its total assets under management to define visibility. In particular, for a 1-year holding period (Table 8), investors in low-visibility funds pay between 29 and 92 basis points less per year than investors in medium-visibility funds. For a 5-year holding period, differences range from 11 to 27 basis points. To put these figures in perspective, consider that a one standard deviation in volatility, an important determinant of fees, increases fees by about 10 basis points (1-year holding period) and 6.4 basis points (5-year holding period). Consistently with our results for persistence, however, high-visibility funds do not charge significantly higher fees than the rest of funds.

Results are different when we use advertising to proxy for visibility. In this case, low advertising is associated with significantly higher total fees and high advertising is associated with significantly lower total fees. One possible interpretation is that management companies use advertising and broker compensation as substitute marketing strategies, so the negative relation between visibility and fees is mechanical. 


\section{Conclusions}

In this paper we ask the question: How does the well-documented familiarity bias affect the nature of competition in the market for financial services? To answer this question we construct a model of the mutual fund market where funds of different qualities compete for investors' money and a fraction of all investors have a preference for more familiar funds. When considering visible funds, these investors perceive higher risk-adjusted performance in the more familiar ones. When considering low-visibility funds, they decide to avoid them altogether. The model predicts that good low-visibility funds will be the only ones catering to investors not prone to familiarity bias: Bad low-visibility funds are driven out of the market and high-visibility funds cater to familiarity-biased investors only. While competition is fierce in the low-visibility segment of the market, it is relaxed by familiarity bias in the high visibility segment. If the intensity of familiarity bias is high enough, bad high-visibility funds are able to survive despite offering lower net performance than good highly visible funds.

Since there is no asymmetric information in our model, there is no role for learning either, so the outcome of a multi-period version of the model is identical to that of the static version presented in the paper. This implies that, to the extent that quality does not change, performance differences among high-visibility funds will persist through time. Among low-visibility funds, however, competition ensures the homogeneity of operating funds, so one would not expect to observe differences in performance. This prediction is new in the literature and forms the basis of our empirical tests. Using data on US domestic equity funds, we show that, consistently with the model prediction, performance persistence over a one year period is prevalent except for low-visibility funds.

Our results are not driven by differences between large and small funds or differences across investment categories. Also, results are robust to the definition of performance. Finally, we are not just capturing differences in performance persistence between retail and institutional funds or brokered and directly sold funds.

We also find evidence that low-visibility funds charge lower fees, which is consistent with then model when the intensity of familiarity bias takes and intermediate value.

Our results unveil a form of segmentation that arises as a consequence of both investor 
heterogeneity in their preference for familiar investment products and product heterogeneity in their visibility to investors. The consequences are important. Investors prone to familiarity bias end up both investing in inferior products and paying prices that do not offset quality differences. The presence of sophisticated investors in the market is not enough to protect them. Unfortunately, entry of new players in the market by itself is not likely to improve things for familiarity-biased investors precisely because of investors' lack of familiarity with new firms. 


\section{References}

Bailey, W., A. Kumar, and D. Ng (2011). Behavioral biases of mutual fund investors. Journal of Financial Economics 102(1), 1-27.

Bekaert, G., K. Hoyem, W. Hu, and E. Ravina (2014). Who is internationally diversified? Evidence from 296 401(k) plans. Working Paper.

Benartzi, S. (2001). Excessive extrapolation and the allocation of 401(k) accounts to company stock. The Journal of Finance 56(5), 1747-1764.

Bergstresser, D., J. Chalmers, and P. Tufano (2009). Assessing the costs and benefits of brokers in the mutual fund industry. Review of Financial Studies 22(10), 4129-4156.

Berk, J. and R. Green (2004). Mutual fund flows and performance in rational markets. Journal of Political Economy 112(6), 1269-1295.

Berk, J. and I. Tonks (2007). Return persistence and fund flows in the worst performing mutual funds. Working paper.

Bessler, W., D. Blake, P. Luckoff, and I. Tonks (2010). Why does mutual fund performance not persist? The impact and interaction of fund flows and manager changes. Working paper.

Busse, J., A. Goyal, and S. Wahal (2010). Performance and persistence in institutional investment management. The Journal of Finance 65(2), 765-790.

Cao, H. H., B. Han, D. Hirshleifer, and H. H. Zhang (2009). Fear of the unknown: Familiarity and economic decisions. Review of Finance 15, 173-206.

Carhart, M. (1997). On persistence in mutual fund performance. Journal of Finance 52(1), $57-82$.

Chen, J., H. Hong, M. Huang, and J. Kubik (2004). Does fund size erode mutual fund performance? The role of liquidity and organization. The American Economic Review 94(5), $1276-1302$.

Christoffersen, S. E., R. Evans, and D. K. Musto (2013). What do consumers fund flows 
maximize? Evidence from their brokers incentives. The Journal of Finance 68(1), 201235.

Del Guercio, D. and J. Reuter (2014). Mutual fund performance and the incentive to generate alpha. The Journal of Finance 69(4), 1673-1704.

Elton, E., M. Gruber, and C. Blake (2011). Does Size Matter? The Relationship Between Size and Performance. Working paper.

Evans, R. (2010). Mutual fund incubation. The Journal of Finance 65(4), 1581-1611.

Ferreira, M. A., A. Keswani, A. F. Miguel, and S. Ramos (2013). Testing the Berk and Green model around the world. Working paper.

French, K. R. and J. M. Poterba (1991). Investor diversification and international equity markets. American Economic Review 81(2), 222-226.

Gennaioli, N., A. Shleifer, and R. Vishny (2015). Money doctors. Journal of Finance (Forthcoming).

Gil-Bazo, J. and P. Ruiz-Verdú (2008). When cheaper is better: Fee determination in the market for equity mutual funds. Journal of Economic Behavior \& Organization 67(3), $871-885$.

Gil-Bazo, J. and P. Ruiz-Verdú (2009). The relation between price and performance in the mutual fund industry. The Journal of Finance 64(5), 2153-2183.

Glode, V., B. Hollifield, M. Kacperczyk, and S. Kogan (2011). Time-varying predictability in mutual fund returns. Working paper.

Grinblatt, M. and M. Keloharju (2001). How distance, language, and culture influence stockholdings and trades. The Journal of Finance 56(3), 1053-1073.

Gruber, M. (1996). Another puzzle: The growth in actively managed mutual funds. Journal of Finance 51(3), 783-810.

Hendricks, D., J. Patel, and R. Zeckhauser (1993). Hot hands in mutual funds: Short-run persistence of relative performance, 1974-1988. Journal of Finance 48(3), 93-130.

Hotelling, A. (1929). Stability in competition. Economic Journal 39, 41-57. 
Huang, J., K. Wei, and H. Yan (2007). Participation costs and the sensitivity of fund flows to past performance. The Journal of Finance 62(3), 1273-1311.

Huberman, G. (2001). Familiarity breeds investment. Review of financial Studies 14(3), 659680.

Ivković, Z. and S. Weisbenner (2005). Local does as local is: Information content of the geography of individual investors' common stock investments. The Journal of Finance 60(1), $267-306$.

Massa, M. and A. Simonov (2006). Hedging, familiarity and portfolio choice. Review of Financial Studies 19(2), 633-685.

Metrick, A. and R. Zeckhauser (1998). Price versus quantity: Market-clearing mechanisms when consumers are uncertain about quality. Journal of Risk and Uncertainty 17(3), $215-243$.

Nanda, V., M. Narayanan, and V. A. Warther (2000). Liquidity, investment ability, and mutual fund structure. Journal of Financial Economics 57(3), 417-443.

Reuter, J. and E. Zitzewitz (2010). How much does size erode mutual fund performance? A regression discontinuity approach. Working paper.

Seasholes, M. S. and N. Zhu (2010). Individual investors and local bias. The Journal of Finance 65(5), 1987-2010.

Sun, Y. (2014). The effect of index fund competition on money management fees. Working paper. 


\section{Appendix}

Proof of Proposition 1. The manager of each fund $\theta v$, with $\theta \in\{G, B\}$ and $v \in\{H, L\}$ solves the following maximization problem

$$
\max _{f_{\theta v} \geq 0} \Pi_{\theta v}=f_{\theta v}\left(q_{U, \theta v}+q_{S, \theta v}\right) .
$$

We have shown that there is segmentation: sophisticated investors do not invest in high-visibility funds, and therefore $q_{S, \theta H}=0$, for $\theta \in\{B, G\}$.

Therefore, we solve for the optimal strategy of $G H$ and $B H$ funds under segmentation. The unsophisticated investor $i$ decides to invest in fund $G H$ if her participation constraint is satisfied, i.e. $U_{i, G H}^{U} \equiv U_{G} \geq 0$. We denote by $x$ the demand of investors for fund $G H$. Since investors have each $\$ 1$ to invest, $x$ is also the location of the investor that is indifferent between investing or not with the fund. Similarly, an investor $j$ decides to invest in fund $B H$ if her participation constraint is satisfied, i.e. $U_{j, B H}^{U} \equiv U_{B} \geq 0$. We denote by $y$ the demand of investors for fund $B H$, and the location of the last investor willing to invest in fund $B H$ is $\lambda_{U}-y$. The fund $G H^{\prime} s$ manager solves the following maximization problem

$$
\begin{aligned}
\max _{f_{G H}} \Pi_{G H} & =f_{G H} x \\
\text { s.t. } U_{G} & =R_{G}-f_{G H}-k x^{2} \geq 0 \\
x+y & \leq \lambda_{U}, \\
f_{G H} & \geq 0,
\end{aligned}
$$

and the fund $B H^{\prime} s$ manager solves

$$
\begin{aligned}
\max _{f_{B H}} \Pi_{B H} & =f_{B H} y \\
\text { s.t. } U_{B} & =R_{B}-f_{B H}-k y^{2} \geq 0 \\
x+y & \leq \lambda_{U}, \\
f_{B H} & \geq 0 .
\end{aligned}
$$


The Lagrangean for the problem of the manager of the $G H$ fund is

$$
\mathcal{L}_{G}=f_{G H} x-\mu_{G}\left(k x^{2}-R_{G}+f_{G H}\right)-\eta\left(x+y-\lambda_{U}\right),
$$

and the one for the problem of the manager of the $B H$ fund is

$$
\mathcal{L}_{B}=f_{B H} x-\mu_{B}\left(k y^{2}-R_{B}+f_{B H}\right)-\eta\left(x+y-\lambda_{U}\right) .
$$

The Kuhn-Tucker conditions for these problems are

$$
\begin{aligned}
\frac{\partial \mathcal{L}_{\theta}}{\partial f_{\theta H}} & \leq 0, \quad f_{\theta H} \geq 0, \quad f_{\theta H} \frac{\partial \mathcal{L}_{\theta}}{\partial f_{\theta H}}=0 \\
U_{\theta} & =R_{\theta}-f_{\theta H}-k x^{2} \geq 0, \quad \mu_{\theta} \geq 0, \quad \mu_{\theta}\left(k x^{2}-R_{\theta}+f_{\theta H}\right)=0 \\
x+y & \leq \lambda_{U}, \quad \eta \geq 0, \quad \eta\left(x+y-\lambda_{U}\right)=0
\end{aligned}
$$

for $\theta \in\{G, B\}$.

Since the manager's profit in case $f_{\theta H}=0$ equals 0 , we consider only the cases when $f_{\theta H}>0$. Therefore, we have

$$
\begin{aligned}
\frac{\partial \mathcal{L}_{G}}{\partial f_{G H}} & =x+f_{G H} \frac{\partial x}{\partial f_{G H}}-\mu_{G}\left(2 k x \frac{\partial x}{\partial f_{G H}}+1\right)-\eta \frac{\partial x}{\partial f_{G H}}=0, \\
\frac{\partial \mathcal{L}_{B}}{\partial f_{B H}} & =y+f_{B H} \frac{\partial y}{\partial f_{B H}}-\mu_{B}\left(2 k y \frac{\partial y}{\partial f_{B H}}+1\right)-\eta \frac{\partial y}{\partial f_{B H}}=0 .
\end{aligned}
$$

Case $1 \mu_{G}=\mu_{B}=\eta=0$

The Kuhn-Tucker conditions (6) imply that in this case

$$
\begin{aligned}
x+f_{G H} \frac{\partial x}{\partial f_{G H}} & =0, \\
y+f_{B H} \frac{\partial y}{\partial f_{B H}} & =0, \\
U_{G} & \geq 0, U_{B} \geq 0 \text { and } x+y \leq \lambda_{U} .
\end{aligned}
$$

Case 1.1 If $x+y<\lambda_{U}$ then $U_{G}=U_{B}=0$ and from here combined with the conditions (7) 
we obtain that both funds act as local monopolies and therefore

$$
\begin{aligned}
f_{G} & =\frac{2}{3} R_{G}, \\
f_{B} & =\frac{2}{3} R_{B}, \\
x & =\sqrt{\frac{R_{G}}{3 k}} \\
y & =\sqrt{\frac{R_{B}}{3 k}} .
\end{aligned}
$$

Since $x+y<\lambda_{U}$, this is possible if and only if $\lambda_{U}>\sqrt{\frac{R_{G}}{3 k}}+\sqrt{\frac{R_{B}}{3 k}}$.

Case 1.2 If $x+y=\lambda_{U}\left(\right.$ notice that this is possible only when $\left.\lambda_{U} \leq \sqrt{\frac{R_{G}}{3 k}}+\sqrt{\frac{R_{B}}{3 k}}\right)$ the unsophisticated investors decide whether to invest in the good fund or the bad fund depending on their location. In this case the market is covered and the two funds compete for attracting the investors. Thus, we have that the marginal investor's location, $x$, satisfies

$$
R_{G}-f_{G H}-k x^{2}=R_{B}-f_{B H}-k\left(\lambda_{U}-x\right)^{2} .
$$

Therefore the marginal investor is located at

$$
x=\frac{\lambda_{U}}{2}+\frac{R_{G}-f_{G H}-\left(R_{B}-f_{B H}\right)}{2 k \lambda_{U}}=\frac{\lambda_{U}}{2}+\frac{r_{G H}-r_{B H}}{2 k \lambda_{U}},
$$

where $r_{G H} \equiv R_{G}-f_{G H}$ and $r_{B H} \equiv R_{B}-f_{B H}$.

It follows

$$
\begin{aligned}
q_{U, G H} & =\frac{\lambda_{U}}{2}+\frac{r_{G H}-r_{B H}}{2 k \lambda_{U}}, \\
q_{U, B H} & =\frac{\lambda_{U}}{2}-\frac{r_{G H}-r_{B H}}{2 k \lambda_{U}} .
\end{aligned}
$$

Therefore the conditions (7) become

$$
\begin{aligned}
& \frac{\lambda_{U}}{2}+\frac{r_{G H}-r_{B H}}{2 k \lambda_{U}}+\left(-\frac{1}{2 k \lambda_{U}}\right) f_{G H}=0, \\
& \frac{\lambda_{U}}{2}-\frac{r_{G H}-r_{B H}}{2 k \lambda_{U}}+\left(-\frac{1}{2 k \lambda_{U}}\right) f_{B H}=0 .
\end{aligned}
$$


Solving for $f_{G H}$ and $f_{B H}$ and imposing that fees are positive we find that in equilibrium

$$
\begin{aligned}
& f_{G H}^{*}=\left\{\begin{array}{cc}
k\left(\lambda_{U}\right)^{2}+\frac{1}{3} \Delta & \text { if } \\
\Delta-k\left(\lambda_{U}\right)^{2} & \text { otherwise, }
\end{array}\right. \\
& f_{B H}^{*}=\left\{\begin{array}{cc}
k\left(\lambda_{U}\right)^{2}-\frac{1}{3} \Delta & \text { if } k\left(\lambda_{U}\right)^{2}-\frac{1}{3} \Delta>0, \\
0 & \text { otherwise, }
\end{array}\right.
\end{aligned}
$$

with $\Delta=\left(R_{G}-R_{B}\right)$. The optimal quantities invested in each fund are therefore equal to

$$
\begin{aligned}
q_{U, G H}^{*} & =\left\{\begin{array}{cc}
\frac{1}{2 k \lambda_{U}}\left(k\left(\lambda_{U}\right)^{2}+\frac{1}{3} \Delta\right) & \text { if } k\left(\lambda_{U}\right)^{2}-\frac{1}{3} \Delta>0, \\
\lambda_{U} & \text { otherwise, }
\end{array}\right. \\
q_{U, B H}^{*} & =\left\{\begin{array}{cc}
\frac{1}{2 k \lambda_{U}}\left(k\left(\lambda_{U}\right)^{2}-\frac{1}{3} \Delta\right) & \text { if } k\left(\lambda_{U}\right)^{2}-\frac{1}{3} \Delta>0, \\
0 & \text { otherwise. }
\end{array}\right.
\end{aligned}
$$

Case $2 \mu_{G}=\mu_{B}=0, \eta \neq 0$

The Kuhn-Tucker conditions (6) imply that $x+y=\lambda_{U}, \eta>0, U_{G} \geq 0, U_{B} \geq 0$ and

$$
\begin{aligned}
& x+\frac{\partial x}{\partial f_{G}}\left(f_{G H}-\eta\right)=0, \\
& y+\frac{\partial y}{\partial f_{B}}\left(f_{B H}-\eta\right)=0 .
\end{aligned}
$$

Since $x+y=\lambda_{U}$, it implies that $U_{G}=U_{B}$ and therefore $x$ is as defined in (8) and therefore

$$
\begin{aligned}
& x+\left(-\frac{1}{2 k \lambda_{U}}\right)\left(f_{G H}-\eta\right)=0, \\
& y+\left(-\frac{1}{2 k \lambda_{U}}\right)\left(f_{B H}-\eta\right)=0 .
\end{aligned}
$$

Consequently, we have that

$$
\begin{aligned}
x & =\left(\frac{1}{2 k \lambda_{U}}\right)\left(f_{G H}-\eta\right), \\
y & =\left(-\frac{1}{2 k \lambda_{U}}\right)\left(f_{B H}-\eta\right) .
\end{aligned}
$$


Since $\eta>0$ the profit of the $G H$ fund manager is $f_{G H} x=\frac{f_{G H}}{2 k \lambda_{U}}\left(f_{G H}-\eta\right)<\frac{\left(f_{G H}^{*}\right)^{2}}{2 k \lambda_{U}}$ and therefore in this case we do not obtain a global optimum.

Case $3 \mu_{G} \neq 0, \mu_{B}=0, \eta \neq 0$

This implies that $x+y=\lambda_{U}, \eta>0, U_{G}=0, \mu_{G}>0$ and $U_{B} \geq 0$. However, since $x+y=\lambda_{U}$. So, we have that

$$
x=\sqrt{\frac{R_{G}-f_{G H}}{k}}
$$

and

$$
\begin{aligned}
\frac{\partial \mathcal{L}_{G}}{\partial f_{G H}} & =x+f_{G H} \frac{\partial x}{\partial f_{G H}}-\mu_{G}\left(2 k x \frac{\partial x}{\partial f_{G H}}+1\right)-\eta \frac{\partial x}{\partial f_{G H}}=0, \\
\frac{\partial \mathcal{L}_{B}}{\partial f_{B H}} & =y+f_{B H} \frac{\partial y}{\partial f_{B H}}-\eta \frac{\partial y}{\partial f_{B H}}=0 .
\end{aligned}
$$

Since $y=\lambda_{U}-x$, we can rewrite $\frac{\partial \mathcal{L}_{B}}{\partial f_{B H}}=\lambda_{U}-x-f_{B H} \frac{\partial x}{\partial f_{B H}}+\eta \frac{\partial x}{\partial f_{B H}}=\lambda_{U}-x$. This implies that $x=\lambda_{U}, y=0$ and $f_{G H}=R_{G}-k\left(\lambda_{U}\right)^{2}$. Finally, we have that $x+\left(f_{G H}-\eta\right) \frac{\partial x}{\partial f_{G H}}=0 \Leftrightarrow$ $\lambda_{U}+\left(f_{G H}-\eta\right)\left(-\frac{1}{2 k \lambda_{U}}\right)=0 \Leftrightarrow 2 k\left(\lambda_{U}\right)^{2}+\eta=f_{G H} \Leftrightarrow \eta=f_{G H}-2 k\left(\lambda_{U}\right)^{2}$.

Therefore $\eta=R_{G}-k\left(\lambda_{U}\right)^{2}-2 k\left(\lambda_{U}\right)^{2}=R_{G}-3 k\left(\lambda_{U}\right)^{2}>0$ if $3 k\left(\lambda_{U}\right)^{2}<R_{G}$.

Case $4 \mu_{G}=0, \mu_{B} \neq 0, \eta \neq 0$

This implies that $x+y=\lambda_{U}, \eta>0, U_{B}=0, \mu_{B}>0$ and $U_{G} \geq 0$. However, since $x+y=\lambda_{U}$ it implies also $U_{G}=0$. So, we have that

$$
\begin{aligned}
& x=\sqrt{\frac{R_{G}-f_{G H}}{k}}, \\
& y=\sqrt{\frac{R_{B}-f_{B H}}{k}},
\end{aligned}
$$

and the conditions (7) become in this case

$$
\begin{aligned}
\frac{\partial \mathcal{L}_{G}}{\partial f_{G H}} & =x+f_{G H} \frac{\partial x}{\partial f_{G H}}-\eta \frac{\partial x}{\partial f_{G H}}=0 \\
\frac{\partial \mathcal{L}_{B}}{\partial f_{B H}} & =y+f_{B H} \frac{\partial y}{\partial f_{B H}}-\mu_{B}\left(2 k y \frac{\partial y}{\partial f_{B H}}+1\right)-\eta \frac{\partial y}{\partial f_{B H}}=0 .
\end{aligned}
$$


Notice that $\left(2 k y \frac{\partial y}{\partial f_{B H}}+1\right)=2 k \sqrt{\frac{R_{B}-f_{B H}}{k}}\left(-\frac{1}{2 k \sqrt{\frac{R_{B}-f_{B H}}{k}}}\right)+1=0$, and therefore this case is reduced to Case 2, where we have proved that the solution obtained is not a global optimum.

Case $5 \mu_{G}=0, \mu_{B} \neq 0, \eta=0$

This implies that $x+y \leq \lambda_{U}, U_{B}=0, \mu_{B}>0$ and $U_{G} \geq 0$. Since $x+y \leq \lambda_{U}, U_{B}=0$ it implies also $U_{G}=0$, so we have

$$
\begin{aligned}
& x=\sqrt{\frac{R_{G}-f_{G H}}{k}}, \\
& y=\sqrt{\frac{R_{B}-f_{B H}}{k}},
\end{aligned}
$$

and therefore the conditions (7) become

$$
\begin{aligned}
\frac{\partial \mathcal{L}_{G}}{\partial f_{G H}} & =x+f_{G H} \frac{\partial x}{\partial f_{G H}}=0, \\
\frac{\partial \mathcal{L}_{B}}{\partial f_{B H}} & =y+f_{B H} \frac{\partial y}{\partial f_{B H}}=0
\end{aligned}
$$

since $\left(2 k y \frac{\partial y}{\partial f_{B H}}+1\right)=2 k \sqrt{\frac{R_{B}-f_{B H}}{k}}\left(-\frac{1}{2 k \sqrt{\frac{R_{B}-f_{B H}}{k}}}\right)+1=0$. Consequently, we have the same solution as in Case 1.1.

Case $6 \mu_{G} \neq 0, \mu_{B}=0, \eta=0$

This implies that $x+y \leq \lambda_{U}, U_{G}=0, \mu_{G}>0$ and $U_{B} \geq 0$. Since $x+y \leq \lambda_{U}, U_{G}=0$ it implies also $U_{B}=0$, so we have again that

$$
\begin{aligned}
& x=\sqrt{\frac{R_{G}-f_{G H}}{k}}, \\
& y=\sqrt{\frac{R_{B}-f_{B H}}{k}} .
\end{aligned}
$$


Therefore the conditions (7) become

$$
\begin{aligned}
\frac{\partial \mathcal{L}_{G}}{\partial f_{G H}} & =x+f_{G H} \frac{\partial x}{\partial f_{G H}}=0, \\
\frac{\partial \mathcal{L}_{B}}{\partial f_{B H}} & =y+f_{B H} \frac{\partial y}{\partial f_{B H}}=0
\end{aligned}
$$

since again $\left(2 k y \frac{\partial x}{\partial f_{G H}}+1\right)=2 k \sqrt{\frac{R_{G}-f_{G H}}{k}}\left(-\frac{1}{2 k \sqrt{\frac{R_{G}-f_{G H}}{k}}}\right)+1=0$. Consequently, we have again the same solution as in Case 1.1.

Case $7 \mu_{G} \neq 0, \mu_{B} \neq 0, \eta=0$

This implies that $x+y \leq \lambda_{U}, U_{B}=0, \mu_{B}>0$ and $U_{G}=0, \mu_{B}>0$. Similarly as in the Cases 5 and 6 we have the same solution as in Case 1.1.

Case $8 \mu_{G} \neq 0, \mu_{B} \neq 0, \eta \neq 0$

This implies that $x+y=\lambda_{U}, U_{B}=0, \mu_{B}>0$ and $U_{G}=0, \mu_{B}>0$ and again we have the same solution as in Case 1.1 if $\lambda_{U}=\sqrt{\frac{R_{G}}{3 k}}+\sqrt{\frac{R_{B}}{3 k}}$.

We compare the possible equilibria to find the global optimum and we obtain that if $\lambda_{U} \geq$ $\sqrt{\frac{R_{G}}{3 k}}+\sqrt{\frac{R_{B}}{3 k}}$ the solution is the one obtained in Case 1.1, otherwise the solution is the one from Case 1.2. We define $k_{0} \equiv \frac{\Delta}{3\left(\lambda_{U}\right)^{2}}$ and $k_{1} \equiv \frac{\left(\sqrt{R_{G}}+\sqrt{R_{B}}\right)^{2}}{3\left(\lambda_{U}\right)^{2}}$. With these notations, the equilibrium fees are

$$
\begin{aligned}
& f_{G H}^{*}=\left\{\begin{array}{ccc}
\Delta-k\left(\lambda_{U}\right)^{2} & \text { if } & k \leq k_{0}, \\
k\left(\lambda_{U}\right)^{2}+\frac{1}{3} \Delta & \text { if } & k_{0}<k<k_{1}, \\
\frac{2}{3} R_{G} & \text { if } & k \geq k_{1},
\end{array},\right. \\
& f_{B H}^{*}=\left\{\begin{array}{ccc}
0 & \text { if } & k \leq k_{0}, \\
k\left(\lambda_{U}\right)^{2}-\frac{1}{3} \Delta & \text { if } & k_{0}<k<k_{1}, \\
\frac{2}{3} R_{B} & \text { if } & k \geq k_{1} .
\end{array}\right.
\end{aligned}
$$


And the optimal quantities invested in each fund are therefore equal to

$$
\begin{aligned}
& q_{U, G H}^{*}=\left\{\begin{array}{clc}
\lambda_{U} & \text { if } & k \leq k_{0}, \\
\frac{1}{2 k \lambda_{U}}\left(k\left(\lambda_{U}\right)^{2}+\frac{1}{3} \Delta\right) & \text { if } & k_{0}<k<k_{1}, \\
\sqrt{\frac{R_{G}}{3 k}} & \text { if } & k \geq k_{1}, \\
0 & \text { if } & k \leq k_{0},
\end{array}\right. \\
& q_{U, B H}^{*}=\left\{\begin{array}{clc}
\frac{1}{2 k \lambda_{U}}\left(k\left(\lambda_{U}\right)^{2}-\frac{1}{3} \Delta\right) & \text { if } & k_{0}<k<k_{1}, \\
\sqrt{\frac{R_{B}}{3 k}} & \text { if } & k \geq k_{1} .
\end{array}\right.
\end{aligned}
$$

Finally, we have to determine the optimal fee for the $G L$ fund. The optimal fee is determined in such a way that the $G H$ fund does not want to mimic the fee of the $G L$ fund. We find next the fee $f_{G L}$ in each of the three cases above, which are determined by the value of $k$.

\section{Case A}

First we considered the case when $k \leq k_{0}$, when the fund $G H$ covers all the market of unsophisticated investors and fund $B H$ does not participate in the market (sets a fee $f_{B H}^{*}=0$ ).

The fee $f$ that makes the manager of the $G H$ fund to be indifferent between operating only with the unsophisticated investors and operating with both unsophisticated and sophisticated investors is such that

$$
f_{G H} q_{U, G H}=f\left(q_{U, G H}\left(f, f_{B H}\right)+\lambda_{S}\right) .
$$

Replacing the optimal values for $f_{G H}, f_{B H}$ and $q_{U, G H}$ in this case we obtain that (9) is equivalent to

$$
\left(\Delta-k \lambda_{U}^{2}\right) \lambda_{U}=f\left(\lambda_{U}+\lambda_{S}\right)
$$

Therefore the manager of the $G L$ fund chooses

$$
f_{G L}^{*}=\min \left\{\Delta, \frac{\lambda_{U}}{\lambda_{S}+\lambda_{U}}\left(\Delta-k \lambda_{U}^{2}\right)\right\}-\varepsilon=\frac{\lambda_{U}}{\lambda_{S}+\lambda_{U}}\left(\Delta-k \lambda_{U}^{2}\right)-\varepsilon,
$$

with $\varepsilon$ positive and small enough, and at this fee the manager of the fund $G H$ does not have incentives to deviate. 


\section{Case B}

In the second case we consider values for $k$ such that $k_{0} \leq k \leq k_{1}$. In this case the market is covered by the two funds. The fee $f$ that makes the manager of the $G H$ fund to be indifferent between operating only with the unsophisticated investors and operating with both unsophisticated and sophisticated investors is such that

$$
f_{G H} q_{U, G H}=f\left(q_{U, G H}\left(f, f_{B H}\right)+\lambda_{S}\right)
$$

We define $T \equiv f_{G H}=\left(k\left(\lambda_{U}\right)^{2}+\frac{1}{3} \Delta\right)$, and $K=k \lambda_{U}$. With these notations the equation (10) can be rewritten as

$$
\frac{T^{2}}{2 K}=f\left(\frac{T}{K}-\frac{f}{2 K}+\lambda_{S}\right)
$$

Notice that in order to be able to serve all the market of sophisticated investors, the manager of the $G H$ fund should deviate to a fee $f<f_{G H}=T$.

We define

$$
G(f) \equiv \frac{T^{2}}{2 K}-f\left(\frac{T}{K}-\frac{f}{2 K}+\lambda_{S}\right)
$$

and it results that

$$
G(f)=\frac{1}{18 k \lambda_{U}}\left(9 f^{2}-18 f k\left(\lambda_{U}\right)^{2}-18 f k \lambda_{U} \lambda_{S}-6 f \Delta+9 k^{2}\left(\lambda_{U}\right)^{4}+6 k \Delta\left(\lambda_{U}\right)^{2}+\Delta^{2}\right) .
$$

We solve for the fee from the equation

$$
9 f^{2}-18 f k\left(\lambda_{U}\right)^{2}-18 f k \lambda_{U} \lambda_{S}-6 f \Delta+9 k^{2}\left(\lambda_{U}\right)^{4}+6 k \Delta\left(\lambda_{U}\right)^{2}+\Delta^{2}=0,
$$

and the solutions are:

$$
f_{1,2}=k\left(\lambda_{U}\right)^{2}+k \lambda_{S} \lambda_{U}+\frac{1}{3} \Delta \pm \frac{\sqrt{3}}{3} \sqrt{k \lambda_{S} \lambda_{U}\left(6 k\left(\lambda_{U}\right)^{2}+3 k \lambda_{S} \lambda_{U}+2 \Delta\right)}
$$


Notice that $f_{1,2}>0$. We define

$$
\begin{aligned}
k_{2}^{*} & \equiv \frac{\Delta}{3\left(\lambda_{U}\right)^{3}}\left(3 \lambda_{S}+2 \lambda_{U}-\sqrt{3} \sqrt{4 \lambda_{S} \lambda_{U}+3\left(\lambda_{S}\right)^{2}}\right) \\
k_{3}^{*} & \equiv \frac{\Delta}{3\left(\lambda_{U}\right)^{3}}\left(3 \lambda_{S}+2 \lambda+\sqrt{3} \sqrt{4 \lambda_{S} \lambda_{U}+3\left(\lambda_{S}\right)^{2}}\right) .
\end{aligned}
$$

We study when $f_{1,2}>\Delta$ and we obtain the following cases depending on the values of $k$.

Case B.1 If $k \in\left(0, k_{2}^{*}\right)$, then $f_{1}<\Delta$ and $f_{2}<\Delta$. In this case it results that $G(f) \geq 0$ for any $f \in\left[0, f_{1}\right] \cup\left[f_{2}, \infty\right)$. Notice that $f_{1}<T<f_{2}$, and therefore for all the fees $f \in\left[f_{2}, \infty\right)$ the manager of the fund $G H$ attracts only unsophisticated investors, so deviating in this range does not increase his profit. Since we have that $f_{1}<T$, the manager of the $G L$ fund chooses $f_{G L}^{*}=f_{1}-\varepsilon$ with $\varepsilon$ positive and small enough.

Case B.2 If $k \in\left(k_{2}^{*}, k_{3}^{*}\right)$, then $f_{1}<\Delta$ and $f_{2}>\Delta$. It results that $G(f)>0$ for any $f \in\left(0, f_{1}\right]$ and $G(f)<0$ for any $f \in\left(f_{1}, \Delta\right)$, so the manager of the $G L$ fund chooses $f_{G L}^{*}=f_{1}-\varepsilon$ with $\varepsilon$ positive and small enough.

Case B.3 If $k \in\left(k_{3}^{*}, \infty\right)$, then $f_{1}>\Delta$ and $f_{2}>\Delta$.It results that $G(f)>0$ for any $f \in[0, \Delta]$ and therefore the manager of the $G L$ fund chooses $f_{G L}^{*}=\Delta-\varepsilon$ with $\varepsilon$ positive and small enough.

From the three cases above we obtain that when $k_{0}<k<k_{1}$ the optimal fee for the $G L$ fund is

$$
\begin{aligned}
f_{G L}^{*}=\left\{\begin{array}{cc}
f^{*}-\varepsilon & \text { if } k \in\left(k_{0}, \max \left\{k_{0}, \min \left\{k_{2}^{*}, k_{1}\right\}\right\}\right), \\
f^{*}-\varepsilon & \text { if } k \in\left(\max \left\{k_{0}, k_{2}^{*}\right\}, \min \left\{k_{3}^{*}, k_{1}\right\}\right), \\
\Delta-\varepsilon & \text { if } k \in\left(\min \left\{k_{3}^{*}, k_{1}\right\}, k_{1}\right),
\end{array}\right. \\
=\left\{\begin{array}{cc}
f^{*}-\varepsilon & \text { if } k \in\left(k_{0}, \min \left\{k_{3}^{*}, k_{1}\right\}\right), \\
\Delta-\varepsilon & \text { if } k \in\left(\min \left\{k_{3}^{*}, k_{1}\right\}, k_{1}\right),
\end{array}\right.
\end{aligned}
$$

where we have defined $f^{*} \equiv f_{1}=k\left(\lambda_{U}\right)^{2}+k \lambda_{S} \lambda_{U}+\frac{1}{3} \Delta-\frac{\sqrt{3}}{3} \sqrt{k \lambda_{S} \lambda_{U}\left(6 k\left(\lambda_{U}\right)^{2}+3 k \lambda_{S} \lambda_{U}+2 \Delta\right)}$. Case C

Finally, we consider the case when the market is not covered, i.e. when $k \geq k_{1}$. As explained above, in this case the fund $G H$ acts as a monopoly. 
The fee $f$ that makes the manager of the $G H$ fund to be indifferent between operating only with the unsophisticated investors and operating with both unsophisticated and sophisticated investors is such that

$$
f_{G H} q_{U, G H}=f\left(q_{U, G H}(f)+\lambda_{S}\right),
$$

where $f_{G H}=\frac{2}{3} R_{G}$ and $q_{U, G H}=\sqrt{\frac{R_{G}}{3 k}}$. Replacing these values (11) becomes

$$
2 k^{-\frac{1}{2}}\left(\frac{R_{G}}{3}\right)^{\frac{3}{2}}=f\left(\sqrt{\frac{R_{G}-f}{k}}+\lambda_{S}\right) .
$$

We define $A \equiv 2 k^{-\frac{1}{2}}\left(\frac{R_{G}}{3}\right)^{\frac{3}{2}}$ and replace the fee $f$ in the equation above with $f=R_{G}-k x^{2}$. With this change of notation we define

$$
H(x) \equiv A-\left(R_{G}-k x^{2}\right)\left(x+\lambda_{S}\right)
$$

Notice that the equation $H^{\prime}(x)=0$ has two solutions $x_{1}=-\frac{1}{3 k}\left(\sqrt{\lambda_{S}^{2} k^{2}+3 R_{G} k}+\lambda_{S} k\right)<0$ and $x_{2}=\frac{1}{3 k}\left(\sqrt{\lambda_{S}^{2} k^{2}+3 R_{G} k}-\lambda_{S} k\right) \in\left[0, \sqrt{\frac{R}{3 k}}\right)$. If $x \in\left(-\infty, x_{1}\right) \cup\left(x_{2},+\infty\right), H^{\prime}(x)>0$, and $H^{\prime}(x) \leq 0$, otherwise.

In order to be able to serve all the market of sophisticated investors, the manager of the $G H$ fund should deviate to a fee $0<f<f_{G H}=\frac{2}{3} R_{G}$. This condition is equivalent to $\sqrt{\frac{R}{3 k}}<$ $x<\sqrt{\frac{R}{k}}$. Therefore, it results that since $x_{2}^{*}<\sqrt{\frac{R_{G}}{3 k}}$, for any $x \in\left[\sqrt{\frac{R_{G}}{3 k}}, \sqrt{\frac{R_{G}}{3 k}}\right], H^{\prime}(x)>0$.

We calculate $H\left(\sqrt{\frac{R_{G}}{3 k}}\right)=-\frac{1}{9} R_{G}\left(6 \lambda_{S}-5 \sqrt{\frac{R_{G}}{3 k}}\right) \geq 0$ if $\lambda_{S} \leq \frac{5}{6} \sqrt{\frac{R_{G}}{3 k}}$, and $H\left(\sqrt{\frac{R}{k}}\right)=$ $A=\frac{2}{3} R_{G} \sqrt{\frac{R_{G}}{3 k}}>0$.

Case C.1 If $\lambda_{S} \leq \frac{5}{6} \sqrt{\frac{R_{G}}{3 k}}$ it implies that $H\left(\sqrt{\frac{R_{G}}{3 k}}\right) \geq 0, H\left(\sqrt{\frac{R_{G}}{3 k}}\right)>0$ and $H^{\prime}(x)>0$ for any $x \in\left[\sqrt{\frac{R_{G}}{3 k}}, \sqrt{\frac{R_{G}}{k}}\right]$. This in turn implies that $H(x) \geq 0$ for any $x \in\left[\sqrt{\frac{R_{G}}{3 k}}, \sqrt{\frac{R_{G}}{3 k}}\right]$ and therefore the manager of the $G L$ fund chooses $f_{G L}^{*}=\min \left\{\Delta, \frac{2}{3} R_{G}\right\}-\varepsilon$ with $\varepsilon$ positive and small enough.

Case C.2 If $\lambda_{S}>\sqrt{\frac{R_{G}}{3 k}}$ it implies that $H\left(\sqrt{\frac{R_{G}}{3 k}}\right)<0, H\left(\sqrt{\frac{R_{G}}{3 k}}\right)>0$ and $H^{\prime}(x)>0$ 
for any $x \in\left[\sqrt{\frac{R_{G}}{3 k}}, \sqrt{\frac{R_{G}}{3 k}}\right]$. It results that there exists $x^{*} \in\left[\sqrt{\frac{R_{G}}{3 k}}, \sqrt{\frac{R_{G}}{3 k}}\right]$ solution of the equation $H(x)=0$, and therefore $H(x) \leq 0$, for any $x \in\left[\sqrt{\frac{R_{G}}{3 k}}, x^{*}\right]$ and $H(x)>0$, for any $x \in$ $\left(x^{*}, \sqrt{\frac{R_{G}}{k}}\right]$. Therefore the manager of the $G L$ fund chooses in this case $f_{G L}^{*}=\min \left\{\Delta, f^{* *}\right\}-\varepsilon$ with $\varepsilon$ positive and small enough, where $f^{* *} \equiv R_{G}-k\left(x^{*}\right)^{2}$.

To summarize, we obtain that, the optimal fee for the $G L$ fund in this case is

$$
f_{G L}^{*}=\left\{\begin{array}{cc}
\frac{\lambda_{U}}{\lambda_{S}+\lambda_{U}}\left(\Delta-k \lambda_{U}^{2}\right)-\varepsilon & \text { if } k \leq k_{0}, \\
\min \left\{\Delta, f^{*}\right\}-\varepsilon & \text { if } k \in\left(k_{0}, k_{1}\right), \\
\min \left\{\Delta, f^{* *}\right\}-\varepsilon & \text { if } k \geq k_{1} .
\end{array}\right.
$$

Proof of Corollary 1. We have that $f_{B H}=k\left(\lambda_{U}\right)^{2}-\frac{1}{3}\left(R_{G}-R_{B}\right)>0=f_{B, L}$.

If $k \in\left(0, k_{0}\right)$ then $f_{G L}^{*}=\frac{\lambda_{U}}{\lambda_{S}+\lambda_{U}}\left(\Delta-k \lambda_{U}^{2}\right)-\varepsilon<\left(\Delta-k \lambda_{U}^{2}\right)=f_{G H}^{*}$.

If $k \in\left(k_{0}, \min \left\{k_{3}^{*}, k_{1}\right\}\right)$ then $f_{G L}^{*}=f_{1}-\varepsilon<\left(k\left(\lambda_{U}\right)^{2}+\frac{1}{3} \Delta\right)=f_{G H}^{*}$.

If $k \in\left(\min \left\{k_{3}^{*}, k_{1}\right\}, k_{1}\right)$ then $f_{G L}^{*}=\Delta-\varepsilon<f_{1}<\left(k\left(\lambda_{U}\right)^{2}+\frac{1}{3} \Delta\right)=f_{G H}^{*}$.

If $k \geq k_{1}$ then $f_{G L}^{*}=\min \left\{\Delta, f^{* *}\right\}-\varepsilon \leq f^{* *}<\frac{2}{3} R_{G}=f_{G H}^{*}$.

Notice that if $k \in\left(k_{0}, k_{1}\right)$, i.e. if the market is covered we have that the average fee in the high visibility sector is

$$
\frac{f_{G H}^{*}+f_{L H}^{*}}{2}=k\left(\lambda_{U}\right)^{2}>\Delta \geq f_{G L}^{*}
$$

So the average fee in the high visibility sector is higher than the fee in the low visibility sector. 


\section{Table 1}

\section{Summary Statistics}

The table shows summary statistics for the sample of US Domestic Equity mutual funds in the 1993-2010 period employed in the paper. $N$ denotes de number of fund-month observations, except in the case of variables measured at the family level, where we only consider a single observation per family and month. $Q 1$ and $Q 3$ denote the 25th and 75th percentiles, respectively. Total net assets are in millions of USD. Age is the number of years since inception of the fund's oldest class. Family age is the age of the family's oldest fund. Loads, fees, turnover ratio, and returns are asset-weighted averages across all classes in the fund.

\begin{tabular}{|c|c|c|c|c|c|c|}
\hline \multicolumn{7}{|l|}{ Panel A: 1993-2000 } \\
\hline Variable & $N$ & Mean & Std. dev. & Q1 & Median & Q3 \\
\hline Total net assets & 84287 & 1333.59 & 4040.44 & 93.31 & 278.9 & 921.88 \\
\hline Annual flow (in \%) & 63369 & 12.24 & 63.35 & -11.43 & -0.02 & 18.18 \\
\hline Age & 84144 & 15.13 & 14.82 & 5.42 & 9.08 & 17.5 \\
\hline Family total net assets & 26998 & 10981.68 & 40743.85 & 228.6 & 1428.47 & 5611.1 \\
\hline Family age & 26987 & 25.86 & 20.68 & 9.67 & 16.25 & 40.5 \\
\hline Front-end load (in \%) & 37433 & 3.36 & 1.96 & 1.73 & 3.76 & 4.75 \\
\hline Back-end load (in \%) & 28188 & 1.43 & 1.37 & 0.32 & 1 & 2.17 \\
\hline Management fee (in \%) & 37991 & 0.74 & 0.24 & 0.6 & 0.75 & 0.9 \\
\hline Expense ratio (in \%) & 71040 & 1.21 & 0.39 & 0.94 & 1.16 & 1.44 \\
\hline $12 \mathrm{~b}-1$ fee (in \%) & 22914 & 0.33 & 0.25 & 0.12 & 0.25 & 0.5 \\
\hline Turnover ratio (in \%) & 70452 & 82.28 & 64.63 & 36.2 & 67 & 109 \\
\hline Return (in \%) & 83929 & 15.17 & 66.71 & -22.03 & 17.44 & 51.83 \\
\hline Carhart's 4-factor alpha (in \%) & 51181 & -0.41 & 26.99 & -13.38 & -0.73 & 11.96 \\
\hline \multicolumn{7}{|l|}{ Panel A: 2001-2010 } \\
\hline Variable & $N$ & Mean & Std. dev. & Q1 & Median & Q3 \\
\hline Total net assets & 186114 & 1256.74 & 4946.26 & 80 & 242.7 & 838.8 \\
\hline Annual flow (in \%) & 145663 & 6.31 & 58.90 & -15.26 & -4.73 & 11.26 \\
\hline Age & 185881 & 14.10 & 12.87 & 6.5 & 10.17 & 16.08 \\
\hline Family total net assets & 43703 & 20925.18 & 91580.15 & 201.1 & 1265.4 & 7738.7 \\
\hline Family age & 43703 & 28.74 & 21.84 & 12.58 & 20.67 & 38.58 \\
\hline Front-end load (in \%) & 97186 & 2.62 & 1.73 & 1.09 & 2.65 & 4.00 \\
\hline Back-end load (in \%) & 75535 & 0.76 & 0.89 & 0.10 & 0.43 & 1.09 \\
\hline Management fee (in \%) & 171168 & 0.72 & 0.25 & 0.59 & 0.75 & 0.89 \\
\hline Expense ratio (in \%) & 170249 & 1.23 & 0.38 & 0.99 & 1.21 & 1.47 \\
\hline $12 \mathrm{~b}-1$ fee (in $\%$ ) & 127940 & 0.29 & 0.23 & 0.09 & 0.25 & 0.44 \\
\hline Turnover ratio (in \%) & 173993 & 82.15 & 64.48 & 35 & 66 & 110 \\
\hline Return (in \%) & 185859 & 4.56 & 65.30 & -29.18 & 11.98 & 45.30 \\
\hline Carhart's 4-factor alpha (in \%) & 130793 & -2.17 & 21.14 & -12.01 & -1.99 & 7.86 \\
\hline
\end{tabular}


Table 2

Differences between Visibility Subsamples

The table compares selected fund characteristics across fund subsamples defined according to fund visibility. Risk-adjusted performance is estimated using Carhart's (1997) four-factor model. $\alpha$ denotes performance in the subsequent 12 months. Assets denotes the fund's assets under management. F-load and B-load denote the fund's asset-weighted front-end load and back-end load, respectively. 12b-1 fee and Man. fee denote the fund's $12 \mathrm{~b}-1$ and management fee, respectively. High denotes the subsample of funds that belong to the top quartile of the monthly distribution of the number of investment categories in the family, family size, family age, or family advertising. Low is defined analogously for the bottom quartile, except for family advertising, in which case Low denotes subsample of funds with no reported advertising expenditures. The number of fund-year observations is reported in parentheses.

\begin{tabular}{|c|c|c|c|c|c|c|c|}
\hline & & Assets & F-load & 12b-1 fee & Man. fee & $\alpha$ & B-load \\
\hline \multirow[t]{6}{*}{ \# Inv Cat } & Low & 525.79 & $0.74 \%$ & $0.12 \%$ & $0.84 \%$ & $-1.51 \%$ & $0.12 \%$ \\
\hline & & $(4360)$ & $(4360)$ & $(3675)$ & (3318) & $(2316)$ & $(4360)$ \\
\hline & High & 2449.55 & $1.63 \%$ & $0.22 \%$ & $0.64 \%$ & $-1.66 \%$ & $0.50 \%$ \\
\hline & & $(4238)$ & $(4238)$ & $(3806)$ & $(3494)$ & $(2621)$ & $(4238)$ \\
\hline & Low-High & -1923.77 & $-0.89 \%$ & $-0.10 \%$ & $0.20 \%$ & $0.15 \%$ & $-0,38 \%$ \\
\hline & S.e & 88.97 & $0.04 \%$ & $0.01 \%$ & $0.01 \%$ & $0.20 \%$ & $0.02 \%$ \\
\hline \multirow[t]{6}{*}{ Family Size } & Low & 186.12 & $0.85 \%$ & $0.14 \%$ & $0.83 \%$ & $-1.55 \%$ & $0.16 \%$ \\
\hline & & $(5580)$ & $(5580)$ & $(4709)$ & $(4276)$ & $(2915)$ & $(5580)$ \\
\hline & High & 3387.16 & $1.71 \%$ & $0.22 \%$ & $0.63 \%$ & $-1.73 \%$ & $0.49 \%$ \\
\hline & & $(5493)$ & $(5493)$ & $(4632)$ & $(4422)$ & $(3622)$ & $(5493)$ \\
\hline & Low-High & -3201.04 & $-0.85 \%$ & $-0.08 \%$ & $0.20 \%$ & $0.18 \%$ & $-0.33 \%$ \\
\hline & S.e. & 118.97 & $0.04 \%$ & $0.00 \%$ & $0.01 \%$ & $0.18 \%$ & $0.02 \%$ \\
\hline \multirow[t]{6}{*}{ Family Age } & Low & 385.02 & $0.69 \%$ & $0.11 \%$ & $0.81 \%$ & $-1.63 \%$ & $0.11 \%$ \\
\hline & & $(5648)$ & $(5648)$ & $(4761)$ & $(4455)$ & $(2622)$ & $(5648)$ \\
\hline & High & 2971.8 & $2.12 \%$ & $0.27 \%$ & $0.63 \%$ & $-1.8 \%$ & $0.52 \%$ \\
\hline & & $(5619)$ & $(5619)$ & $(4739)$ & $(4488)$ & $(3692)$ & $(5619)$ \\
\hline & Low-High & -2586.78 & $-1.43 \%$ & $-0.15 \%$ & $0.18 \%$ & $0.16 \%$ & $-0.41 \%$ \\
\hline & S.e. & 117.58 & $0.03 \%$ & $0.00 \%$ & $0.01 \%$ & $0.18 \%$ & $0.01 \%$ \\
\hline \multirow[t]{6}{*}{ Family Adv. } & Low & 1210.00 & $1.38 \%$ & $0.21 \%$ & $0.74 \%$ & $-1.91 \%$ & $0.37 \%$ \\
\hline & & $(15888)$ & $(15888)$ & (14414) & $(13380)$ & $(9721)$ & $(15888)$ \\
\hline & High & 2969.95 & $1.36 \%$ & $0.19 \%$ & $0.64 \%$ & $-1.07 \%$ & $0.13 \%$ \\
\hline & & $(822)$ & $(822)$ & $(776)$ & $(731)$ & $(610)$ & $(822)$ \\
\hline & Low-High & -1759.95 & $0.02 \%$ & $0.02 \%$ & $0.10 \%$ & $-0.84 \%$ & $0.24 \%$ \\
\hline & S.e. & 175.65 & $0.07 \%$ & $0.01 \%$ & $0.01 \%$ & $0.30 \%$ & $0.03 \%$ \\
\hline
\end{tabular}


Table 3

Performance Persistence and Fund Visibility

The table reports the estimated coefficients of monthly regressions of fund annual performance on past annual performance and selected fund characteristics in the 1996-2010 period. Risk-adjusted performance is estimated using Carhart's (1997) four-factor model. $\alpha$ denotes performance over the prior 12 months. size denotes the natural logarithm of the fund's assets under management, lagged one year. flow is the net growth in fund's assets during the last 12 months. age is the natural logarithm of the number of months since the inception date of the fund's oldest class, fam_size and fam_age, denote the size the fund's family and the age of the oldest class in the fund's family. F-load and B-load denote the fund's asset-weighted front-end load and back-end load, lagged one year, respectively. turnover denotes the fund's asset-weighted turnover. Regressors include month dummies. HI is a dummy variable that equals one if the fund belongs to the top quartile of the monthly distribution of: the number of investment categories in the family (column 2); family size (column 3); family age (column 4); or family advertising (column 5). LO is defined analogously for the bottom quartile, except in column 4 where it equals one if the fund's family has no reported advertising expenditures. Standard errors are clustered by both fund and month. ${ }^{* *}, * *$, and $*$ indicate significance at the $1 \%, 5 \%$, and $10 \%$ levels, respectively

\begin{tabular}{|c|c|c|c|c|c|}
\hline & (1) & $\begin{array}{c}(2) \\
\text { \#Inv Cat }\end{array}$ & $\begin{array}{c}(3) \\
\text { Family Size }\end{array}$ & $\begin{array}{c}(4) \\
\text { Family Age }\end{array}$ & $\begin{array}{c}(5) \\
\text { Family Adv. }\end{array}$ \\
\hline$\alpha$ & $\begin{array}{c}0.071^{* * *} \\
(0.019)\end{array}$ & $\begin{array}{c}0.085^{* * *} \\
(0.022)\end{array}$ & $\begin{array}{c}0.088^{* * *} \\
(0.023)\end{array}$ & $\begin{array}{c}0.090^{* * *} \\
(0.022)\end{array}$ & $\begin{array}{c}0.113^{* * *} \\
(0.029)\end{array}$ \\
\hline size & $\begin{array}{c}-0.003^{* * *} \\
(0.001)\end{array}$ & $\begin{array}{c}-0.003^{* * *} * \\
(0.001)\end{array}$ & $\begin{array}{c}-0.003^{* * *} \\
(0.001)\end{array}$ & $\begin{array}{c}-0.002^{* * *} \\
(0.001)\end{array}$ & $\begin{array}{c}-0.002^{* * *} \\
(0.001)\end{array}$ \\
\hline flow & $\begin{array}{c}-0.005^{* *} \\
(0.002)\end{array}$ & $\begin{array}{c}-0.005^{* *} \\
(0.002)\end{array}$ & $\begin{array}{c}-0.005^{* *} \\
(0.002)\end{array}$ & $\begin{array}{c}-0.004^{* *} \\
(0.002)\end{array}$ & $\begin{array}{c}-0.004^{* *} \\
(0.002)\end{array}$ \\
\hline age & $\begin{array}{c}0.000 \\
(0.001)\end{array}$ & $\begin{array}{c}0.000 \\
(0.001)\end{array}$ & $\begin{array}{c}0.000 \\
(0.001)\end{array}$ & $\begin{array}{c}0.000 \\
(0.001)\end{array}$ & $\begin{array}{c}0.001 \\
(0.001)\end{array}$ \\
\hline fam_size & $\begin{array}{c}0.001^{* *} \\
(0.000)\end{array}$ & $\begin{array}{c}0.001^{* *} \\
(0.001)\end{array}$ & $\begin{array}{c}0.003^{* * *} * \\
(0.001)\end{array}$ & $\begin{array}{c}0.001^{* *} \\
(0.000)\end{array}$ & $\begin{array}{c}0.001 \\
(0.001)\end{array}$ \\
\hline fam_age & $\begin{array}{l}-0.000 \\
(0.001)\end{array}$ & $\begin{array}{l}-0.000 \\
(0.001)\end{array}$ & $\begin{array}{l}-0.000 \\
(0.001)\end{array}$ & $\begin{array}{l}-0.001 \\
(0.002)\end{array}$ & $\begin{array}{l}-0.001 \\
(0.001)\end{array}$ \\
\hline F-load & $\begin{array}{c}0.021 \\
(0.034)\end{array}$ & $\begin{array}{c}0.026 \\
(0.034)\end{array}$ & $\begin{array}{c}0.021 \\
(0.034)\end{array}$ & $\begin{array}{c}0.024 \\
(0.034)\end{array}$ & $\begin{array}{c}0.032 \\
(0.038)\end{array}$ \\
\hline B-load & $\begin{array}{c}-0.329 * * * \\
(0.106)\end{array}$ & $\begin{array}{c}-0.317^{* * * *} \\
(0.105)\end{array}$ & $\begin{array}{c}-0.335^{* * *} \\
(0.106)\end{array}$ & $\begin{array}{c}-0.328^{* * * *} \\
(0.105)\end{array}$ & $\begin{array}{c}-0.315^{* * *} \\
(0.122)\end{array}$ \\
\hline $\exp$ & $\begin{array}{c}-0.619^{* *} \\
(0.275)\end{array}$ & $\begin{array}{c}-0.615^{* *} \\
(0.275)\end{array}$ & $\begin{array}{c}-0.554^{* *} \\
(0.277)\end{array}$ & $\begin{array}{c}-0.637^{* *} \\
(0.275)\end{array}$ & $\begin{array}{c}-0.551^{*} \\
(0.295)\end{array}$ \\
\hline turnover & $\begin{array}{c}-0.003^{*} \\
(0.002)\end{array}$ & $\begin{array}{c}-0.003^{*} \\
(0.002)\end{array}$ & $\begin{array}{l}-0.003^{*} \\
(0.002)\end{array}$ & $\begin{array}{c}-0.003^{*} \\
(0.002)\end{array}$ & $\begin{array}{c}-0.003 \\
(0.002)\end{array}$ \\
\hline$\alpha \times \mathrm{LO}$ & & $\begin{array}{c}-0.076^{* *} \\
(0.031)\end{array}$ & $\begin{array}{c}-0.059^{*} \\
(0.031)\end{array}$ & $\begin{array}{c}-0.078^{* * *} \\
(0.030)\end{array}$ & $\begin{array}{c}-0.052^{* *} \\
(0.026)\end{array}$ \\
\hline$\alpha \times \mathrm{HI}$ & & $\begin{array}{c}-0.015 \\
(0.025)\end{array}$ & $\begin{array}{l}-0.018 \\
(0.025)\end{array}$ & $\begin{array}{l}-0.021 \\
(0.022)\end{array}$ & $\begin{array}{c}-0.048 \\
(0.049)\end{array}$ \\
\hline LO & & $\begin{array}{c}0.003 \\
(0.002)\end{array}$ & $\begin{array}{c}0.006^{* *} \\
(0.003)\end{array}$ & $\begin{array}{l}-0.003 \\
(0.003)\end{array}$ & $\begin{array}{c}-0.005^{* * *} \\
(0.002)\end{array}$ \\
\hline HI & & $\begin{array}{c}0.001 \\
(0.002)\end{array}$ & $\begin{array}{c}-0.004^{*} \\
(0.002)\end{array}$ & $\begin{array}{l}-0.001 \\
(0.002)\end{array}$ & $\begin{array}{l}-0.001 \\
(0.003)\end{array}$ \\
\hline Time Fixed Effects & Yes & Yes & Yes & Yes & Yes \\
\hline Observations & 108,524 & 108,524 & 108,524 & 108,524 & 101,098 \\
\hline Adjusted R-squared & 0.074 & 0.075 & 0.075 & 0.074 & 0.076 \\
\hline
\end{tabular}


Table 4

Performance Persistence: The Role of Fund Size and Investment Categories

The table reports the estimated coefficients of monthly regressions of fund annual performance on past annual performance and selected fund characteristics in the 1996-2010 period. Risk-adjusted performance is estimated using Carhart's (1997) four-factor model. $\alpha$ denotes performance over the prior 12 months. Controls include: size, flow, age, family size, family age, front-end and back-end loads, and portfolio turnover, as defined in Table 3. Regressors include dummy variables for months, investment categories, and interactions of investment categories with performance. HI is a dummy variable that equals one if the fund belongs to the top quartile of the monthly distribution of: the number of investment categories in the family (column 2); family size (column 3); family age (column 4); or family advertising (column 5). LO is defined analogously for the bottom quartile, except in column 4 where it equals one if the fund's family has no reported advertising expenditures. Standard errors are clustered by both fund and month. $* * *, * *$, and $*$ indicate significance at the $1 \%, 5 \%$, and $10 \%$ levels, respectively

\begin{tabular}{|c|c|c|c|c|c|}
\hline & (1) & $\begin{array}{c}(2) \\
\text { \#Inv Cat }\end{array}$ & $\begin{array}{c}(3) \\
\text { Family Size }\end{array}$ & $\begin{array}{c}(4) \\
\text { Family Age }\end{array}$ & $\begin{array}{c}(5) \\
\text { Family Adv. }\end{array}$ \\
\hline$\alpha$ & $\begin{array}{c}0.171^{* * *} \\
(0.043)\end{array}$ & $\begin{array}{c}0.186^{* * *} \\
(0.044)\end{array}$ & $\begin{array}{c}0.181^{* * *} \\
(0.044)\end{array}$ & $\begin{array}{c}0.185^{* * *} \\
(0.045)\end{array}$ & $\begin{array}{c}0.221^{* * * *} \\
(0.058)\end{array}$ \\
\hline size & $\begin{array}{c}-0.003^{* * * *} \\
(0.001)\end{array}$ & $\begin{array}{c}-0.003^{* * * *} \\
(0.001)\end{array}$ & $\begin{array}{c}-0.003^{* * *} \\
(0.001)\end{array}$ & $\begin{array}{c}-0.003^{* * *} \\
(0.001)\end{array}$ & $\begin{array}{c}-0.002^{* * *} \\
(0.001)\end{array}$ \\
\hline flow & $\begin{array}{c}-0.005^{* *} \\
(0.002)\end{array}$ & $\begin{array}{c}-0.005^{* *} \\
(0.002)\end{array}$ & $\begin{array}{c}-0.005^{* *} \\
(0.002)\end{array}$ & $\begin{array}{c}-0.005^{* *} \\
(0.002)\end{array}$ & $\begin{array}{c}-0.004^{* *} \\
(0.002)\end{array}$ \\
\hline age & $\begin{array}{c}0.001 \\
(0.001)\end{array}$ & $\begin{array}{c}0.001 \\
(0.001)\end{array}$ & $\begin{array}{c}0.001 \\
(0.001)\end{array}$ & $\begin{array}{c}0.001 \\
(0.001)\end{array}$ & $\begin{array}{c}0.001 \\
(0.001)\end{array}$ \\
\hline fam_size & $\begin{array}{c}0.001^{* * * *} \\
(0.000)\end{array}$ & $\begin{array}{c}0.002^{* * *} \\
(0.001)\end{array}$ & $\begin{array}{c}0.003^{* * *} \\
(0.001)\end{array}$ & $\begin{array}{c}0.001^{* * *} \\
(0.000)\end{array}$ & $\begin{array}{l}0.001^{*} \\
(0.000)\end{array}$ \\
\hline fam_age & $\begin{array}{l}-0.000 \\
(0.001)\end{array}$ & $\begin{array}{l}-0.000 \\
(0.001)\end{array}$ & $\begin{array}{l}-0.000 \\
(0.001)\end{array}$ & $\begin{array}{l}-0.000 \\
(0.002)\end{array}$ & $\begin{array}{l}-0.001 \\
(0.001)\end{array}$ \\
\hline F-load & $\begin{array}{c}0.025 \\
(0.034)\end{array}$ & $\begin{array}{c}0.029 \\
(0.034)\end{array}$ & $\begin{array}{c}0.026 \\
(0.034)\end{array}$ & $\begin{array}{c}0.027 \\
(0.034)\end{array}$ & $\begin{array}{c}0.036 \\
(0.038)\end{array}$ \\
\hline B-load & $\begin{array}{c}-0.339^{* * *} \\
(0.103)\end{array}$ & $\begin{array}{c}-0.328^{* * * *} \\
(0.103)\end{array}$ & $\begin{array}{c}-0.349^{* * * *} \\
(0.104)\end{array}$ & $\begin{array}{c}-0.340^{* * *} \\
(0.102)\end{array}$ & $\begin{array}{c}-0.324^{* * *} \\
(0.117)\end{array}$ \\
\hline $\exp$ & $\begin{array}{c}-0.622^{* *} \\
(0.260)\end{array}$ & $\begin{array}{c}-0.618^{* *} \\
(0.260)\end{array}$ & $\begin{array}{c}-0.552^{* *} \\
(0.263)\end{array}$ & $\begin{array}{c}-0.626^{* *} \\
(0.259)\end{array}$ & $\begin{array}{c}-0.567^{* *} \\
(0.277)\end{array}$ \\
\hline turnover & $\begin{array}{l}-0.002 \\
(0.001)\end{array}$ & $\begin{array}{l}-0.002 \\
(0.001)\end{array}$ & $\begin{array}{l}-0.002 \\
(0.001)\end{array}$ & $\begin{array}{l}-0.002 \\
(0.001)\end{array}$ & $\begin{array}{l}-0.001 \\
(0.002)\end{array}$ \\
\hline$\alpha \times \mathrm{LO}$ & & $\begin{array}{c}-0.096^{* * * *} \\
(0.028)\end{array}$ & $\begin{array}{c}-0.089^{* * * *} \\
(0.031)\end{array}$ & $\begin{array}{c}-0.088^{* * * *} \\
(0.030)\end{array}$ & $\begin{array}{c}-0.058^{* *} \\
(0.025)\end{array}$ \\
\hline$\alpha \times \mathrm{HI}$ & & $\begin{array}{c}0.005 \\
(0.025)\end{array}$ & $\begin{array}{c}0.019 \\
(0.027)\end{array}$ & $\begin{array}{l}-0.004 \\
(0.022)\end{array}$ & $\begin{array}{l}-0.028 \\
(0.047)\end{array}$ \\
\hline $\mathrm{LO}$ & & $\begin{array}{c}0.002 \\
(0.002)\end{array}$ & $\begin{array}{l}0.005^{*} \\
(0.003)\end{array}$ & $\begin{array}{c}-0.003 \\
(0.003)\end{array}$ & $\begin{array}{c}-0.006^{* * *} \\
(0.002)\end{array}$ \\
\hline HI & & $\begin{array}{c}0.000 \\
(0.002)\end{array}$ & $\begin{array}{l}-0.003 \\
(0.002)\end{array}$ & $\begin{array}{l}-0.001 \\
(0.002)\end{array}$ & $\begin{array}{l}-0.001 \\
(0.003)\end{array}$ \\
\hline$\alpha \mathrm{x}$ size & $\begin{array}{l}-0.003 \\
(0.007)\end{array}$ & $\begin{array}{l}-0.008 \\
(0.007)\end{array}$ & $\begin{array}{l}-0.016^{*} \\
(0.009)\end{array}$ & $\begin{array}{l}-0.007 \\
(0.007)\end{array}$ & $\begin{array}{l}-0.005 \\
(0.007)\end{array}$ \\
\hline Time Fixed Effects & Yes & Yes & Yes & Yes & Yes \\
\hline Inv. Cat. Fixed Effects & Yes & Yes & Yes & Yes & Yes \\
\hline Inv. Cat. Interactions & Yes & Yes & Yes & Yes & Yes \\
\hline $\begin{array}{l}\text { Observations } \\
\text { Adjusted R-squared }\end{array}$ & $\begin{array}{c}108,524 \\
0.090\end{array}$ & $\begin{array}{c}108,524 \\
0.091\end{array}$ & $\begin{array}{c}108,524 \\
0.091\end{array}$ & $\begin{array}{c}108,524 \\
0.091\end{array}$ & $\begin{array}{c}101,098 \\
0.094\end{array}$ \\
\hline
\end{tabular}


Table 5

Performance Persistence of Recent Winners and Losers: Ranking on Risk-Adjusted Performance

The table reports the estimated coefficients of monthly regressions of fund annual risk-adjusted performance on past annual risk-adjusted performance and selected fund characteristics in the 1996-2010 period. Risk-adjusted performance is estimated using Carhart's (1997) four-factor model. $\alpha$ denotes performance over the prior 12 months. dec $n n$ is a dummy variable that equals one if the fund belongs to the $n$-th decile of the monthly distribution of past performance. Coefficients for control variables are not reported. Controls include: size, flow, age, family size, family age, front-end and back-end loads, and portfolio turnover, as defined in Table 3. Regressors include month dummies. HI is a dummy variable that equals one if the fund belongs to the top quartile of the monthly distribution of: the number of investment categories in the family (column 2); family size (column 3); family age (column 4); or family advertising (column 5). LO is defined analogously for the bottom quartile, except in column 4 where it equals one if the fund's family has no reported advertising expenditures. Standard errors are clustered by both fund and month. ${ }^{* * *},{ }^{* *}$, and ${ }^{*}$ indicate significance at the $1 \%, 5 \%$, and $10 \%$ levels, respectively

\begin{tabular}{|c|c|c|c|c|c|}
\hline & (1) & $\begin{array}{c}(2) \\
\text { \#Inv Cat }\end{array}$ & $\begin{array}{c}(3) \\
\text { Family Size }\end{array}$ & $\begin{array}{c}\text { (4) } \\
\text { Family Age }\end{array}$ & $\begin{array}{c}(5) \\
\text { Family Adv. }\end{array}$ \\
\hline dec_1 $1(\alpha)$ (bottom) & $\begin{array}{c}-0.008^{* * *} \\
(0.002)\end{array}$ & $\begin{array}{c}-0.012^{* * *} \\
(0.003)\end{array}$ & $\begin{array}{c}-0.010^{* * *} \\
(0.003)\end{array}$ & $\begin{array}{c}-0.009 * * * \\
(0.003)\end{array}$ & $\begin{array}{c}-0.009^{*} \\
(0.005)\end{array}$ \\
\hline dec_2 $2(\alpha)$ & $\begin{array}{c}-0.004^{* * * *} \\
(0.001)\end{array}$ & $\begin{array}{c}-0.005^{* * * *} \\
(0.002)\end{array}$ & $\begin{array}{c}-0.003^{*} \\
(0.002)\end{array}$ & $\begin{array}{c}-0.005^{* *} \\
(0.002)\end{array}$ & $\begin{array}{c}-0.006^{*} \\
(0.003)\end{array}$ \\
\hline $\operatorname{dec}_{-} 3(\alpha)$ & $-0.003^{* * *}$ & $\begin{array}{c}-0.003 * * * \\
(0.001)\end{array}$ & $\begin{array}{c}-0.003^{* *} \\
(0.001)\end{array}$ & $\begin{array}{c}-0.003^{* * *} \\
(0.001)\end{array}$ & $\begin{array}{l}-0.001 \\
(0.002)\end{array}$ \\
\hline dec $\_8(\alpha)$ & $\begin{array}{c}0.003^{* * *} \\
(0.001)\end{array}$ & $\begin{array}{c}0.003^{* *} \\
(0.001)\end{array}$ & $\begin{array}{c}0.003^{* *} \\
(0.001)\end{array}$ & $\begin{array}{c}0.003^{* *} \\
(0.001)\end{array}$ & $\begin{array}{c}0.001 \\
(0.002)\end{array}$ \\
\hline dec_9 $9(\alpha)$ & $\begin{array}{c}0.006^{* * *} \\
(0.002)\end{array}$ & $\begin{array}{c}0.006^{* * *} * \\
(0.002)\end{array}$ & $\begin{array}{c}0.008^{* * *} * \\
(0.002)\end{array}$ & $\begin{array}{c}0.007 * * * \\
(0.002)\end{array}$ & $\begin{array}{c}0.008^{* * *} \\
(0.003)\end{array}$ \\
\hline dec $_{-} 10(\alpha)($ top $)$ & $\begin{array}{c}0.010^{* * *} \\
(0.003)\end{array}$ & $\begin{array}{c}0.014^{* * *} \\
(0.004)\end{array}$ & $\begin{array}{c}0.015^{* * *} \\
(0.004)\end{array}$ & $\begin{array}{c}0.014^{* * * *} \\
(0.003)\end{array}$ & $\begin{array}{c}0.020^{* * *} \\
(0.006)\end{array}$ \\
\hline $\mathrm{dec}_{-} 1(\alpha) \times \mathrm{LO}$ & & $\begin{array}{c}0.012^{* *} \\
(0.005)\end{array}$ & $\begin{array}{c}0.010^{* *} \\
(0.005)\end{array}$ & $\begin{array}{l}0.009^{*} \\
(0.005)\end{array}$ & $\begin{array}{c}0.000 \\
(0.005)\end{array}$ \\
\hline dec_2 $(\alpha) \times$ LO & & $\begin{array}{c}0.003 \\
(0.003)\end{array}$ & $\begin{array}{l}-0.000 \\
(0.003)\end{array}$ & $\begin{array}{c}0.002 \\
(0.003)\end{array}$ & $\begin{array}{c}0.003 \\
(0.003)\end{array}$ \\
\hline dec__3 $(\alpha)$ x LO & & $\begin{array}{c}0.006^{* * * *} \\
(0.002)\end{array}$ & $\begin{array}{c}0.003 \\
(0.002)\end{array}$ & $\begin{array}{c}0.007^{* *} \\
(0.003)\end{array}$ & $\begin{array}{l}-0.001 \\
(0.002)\end{array}$ \\
\hline dec $\_1(\alpha)$ x HI & & $\begin{array}{c}0.006 \\
(0.004)\end{array}$ & $\begin{array}{l}-0.003 \\
(0.004)\end{array}$ & $\begin{array}{l}-0.001 \\
(0.004)\end{array}$ & $\begin{array}{l}0.017^{* *} \\
(0.008)\end{array}$ \\
\hline dec_2 $(\alpha)$ x HI & & $\begin{array}{c}0.002 \\
(0.003)\end{array}$ & $\begin{array}{l}-0.003 \\
(0.003)\end{array}$ & $\begin{array}{c}0.001 \\
(0.003)\end{array}$ & $\begin{array}{l}-0.002 \\
(0.007)\end{array}$ \\
\hline dec $\_3(\alpha)$ x HI & & $\begin{array}{l}-0.001 \\
(0.002)\end{array}$ & $\begin{array}{l}-0.001 \\
(0.002)\end{array}$ & $\begin{array}{l}-0.001 \\
(0.002)\end{array}$ & $\begin{array}{l}-0.003 \\
(0.005)\end{array}$ \\
\hline dec_8 $(\alpha)$ x LO & & $\begin{array}{l}-0.004^{*} \\
(0.002)\end{array}$ & $\begin{array}{l}-0.004^{*} \\
(0.002)\end{array}$ & $\begin{array}{l}-0.004 \\
(0.002)\end{array}$ & $\begin{array}{c}0.001 \\
(0.002)\end{array}$ \\
\hline dec_9 $(\alpha) \times$ LO & & $\begin{array}{l}-0.001 \\
(0.003)\end{array}$ & $\begin{array}{l}-0.004 \\
(0.003)\end{array}$ & $\begin{array}{l}-0.004 \\
(0.003)\end{array}$ & $\begin{array}{l}-0.003 \\
(0.003)\end{array}$ \\
\hline dec $\__{-} 10(\alpha) \times \mathrm{LO}$ & & $\begin{array}{c}-0.016^{* * *} \\
(0.005)\end{array}$ & $\begin{array}{c}-0.014^{* * *} \\
(0.005)\end{array}$ & $\begin{array}{c}-0.011^{* *} \\
(0.005)\end{array}$ & $\begin{array}{c}-0.013^{* *} \\
(0.005)\end{array}$ \\
\hline dec_8 $(\alpha) \times \mathrm{HI}$ & & $\begin{array}{c}0.003 \\
(0.002)\end{array}$ & $\begin{array}{c}0.001 \\
(0.002)\end{array}$ & $\begin{array}{c}0.002 \\
(0.002)\end{array}$ & $\begin{array}{l}0.011^{* *} \\
(0.004)\end{array}$ \\
\hline dec_9 $(\alpha)$ x HI & & $\begin{array}{c}0.003 \\
(0.003)\end{array}$ & $\begin{array}{l}-0.004 \\
(0.003)\end{array}$ & $\begin{array}{l}-0.000 \\
(0.003)\end{array}$ & $\begin{array}{c}0.004 \\
(0.005)\end{array}$ \\
\hline dec_ $\_10(\alpha)$ x HI & & $\begin{array}{l}-0.005 \\
(0.005)\end{array}$ & $\begin{array}{l}-0.008 \\
(0.006)\end{array}$ & $\begin{array}{l}-0.007 \\
(0.005)\end{array}$ & $\begin{array}{l}-0.001 \\
(0.010)\end{array}$ \\
\hline LO & & $0.004^{*}$ & $0.008^{* * *}$ & -0.002 & $-0.003^{*}$ \\
\hline $\mathrm{HI}$ & & $\begin{array}{l}(0.002) \\
-0.000 \\
(0.002)\end{array}$ & $\begin{array}{l}(0.003) \\
-0.002 \\
(0.002)\end{array}$ & $\begin{array}{l}(0.002) \\
-0.001 \\
(0.002)\end{array}$ & $\begin{array}{l}(0.002) \\
-0.002 \\
(0.003)\end{array}$ \\
\hline $\begin{array}{l}\text { Time Fixed Effects } \\
\text { Controls }\end{array}$ & $\begin{array}{l}\text { Yes } \\
\text { Yes }\end{array}$ & $\begin{array}{l}\text { Yes } \\
\text { Yes }\end{array}$ & $\begin{array}{l}\text { Yes } \\
\text { Yes }\end{array}$ & $\begin{array}{l}\text { Yes } \\
\text { Yes }\end{array}$ & $\begin{array}{l}\text { Yes } \\
\text { Yes }\end{array}$ \\
\hline $\begin{array}{l}\text { Observations } \\
\text { R-squared }\end{array}$ & $\begin{array}{c}108,524 \\
0.076\end{array}$ & $\begin{array}{c}108,524 \\
0.077\end{array}$ & $\begin{array}{c}108,524 \\
0.078\end{array}$ & $\begin{array}{c}108,524 \\
0.077\end{array}$ & $\begin{array}{c}101,098 \\
0.079\end{array}$ \\
\hline
\end{tabular}


Table 6

Performance Persistence of Recent Winners and Losers: Ranking on Raw Returns

The table reports the estimated coefficients of monthly regressions of fund annual risk-adjusted performance on past annual returns and selected fund characteristics in the 1996-2010 period. Risk-adjusted performance is estimated using Carhart's (1997) four-factor model. ret denotes fund returns in the last 12 months. dec $n$ is a dummy variable that equals one if the fund belongs to the $n$-th decile of the monthly distribution of past performance. Coefficients for control variables are not reported. Controls include: size, flow, age, family size, family age, front-end and back-end loads, and portfolio turnover, as defined in Table 3. Regressors include month dummies. HI is a dummy variable that equals one if the fund belongs to the top quartile of the monthly distribution of: the number of investment categories in the family (column 2); family size (column 3); family age (column 4); or family advertising (column 5 ). LO is defined analogously for the bottom quartile, except in column 4 where it equals one if the fund's family has no reported advertising expenditures. Standard errors are clustered by both fund and month. $* * *,{ }^{* *}$, and $*$ indicate significance at the $1 \%, 5 \%$, and $10 \%$ levels, respectively

\begin{tabular}{|c|c|c|c|c|c|}
\hline & (1) & $\begin{array}{c}(2) \\
\text { \#Inv Cat }\end{array}$ & $\begin{array}{c}\text { (3) } \\
\text { Family Size }\end{array}$ & $\begin{array}{c}(4) \\
\text { Family Age }\end{array}$ & $\begin{array}{c}\text { (5) } \\
\text { Family Adv }\end{array}$ \\
\hline dec_1(ret) & $\begin{array}{c}-0.009^{* * *} \\
(0.003)\end{array}$ & $\begin{array}{c}-0.013^{* * *} \\
(0.003)\end{array}$ & $\begin{array}{c}-0.012^{* * *} \\
(0.003)\end{array}$ & $\begin{array}{c}-0.012^{* * *} \\
(0.003)\end{array}$ & $\begin{array}{l}-0.009 \\
(0.005)\end{array}$ \\
\hline dec_2(ret) & $\begin{array}{c}-0.004^{* * *} \\
(0.002)\end{array}$ & $\begin{array}{c}-0.006^{* * *} \\
(0.002)\end{array}$ & $\begin{array}{c}-0.007^{* * * *} \\
(0.002)\end{array}$ & $\begin{array}{c}-0.004^{* *} \\
(0.002)\end{array}$ & $\begin{array}{l}-0.004 \\
(0.004)\end{array}$ \\
\hline dec_3(ret) & $\begin{array}{c}-0.003^{* *} \\
(0.001)\end{array}$ & $\begin{array}{c}-0.004^{* *} \\
(0.002)\end{array}$ & $\begin{array}{c}-0.003^{* *} \\
(0.002)\end{array}$ & $\begin{array}{c}-0.003^{*} \\
(0.002)\end{array}$ & $\begin{array}{c}0.000 \\
(0.003)\end{array}$ \\
\hline dec_8(ret) & $\begin{array}{c}0.000 \\
(0.001)\end{array}$ & $\begin{array}{l}-0.000 \\
(0.002)\end{array}$ & $\begin{array}{c}-0.001 \\
(0.002)\end{array}$ & $\begin{array}{c}0.001 \\
(0.002)\end{array}$ & $\begin{array}{c}0.002 \\
(0.003)\end{array}$ \\
\hline dec_9(ret) & $\begin{array}{c}0.002 \\
(0.002)\end{array}$ & $\begin{array}{c}0.001 \\
(0.002)\end{array}$ & $\begin{array}{c}0.002 \\
(0.002)\end{array}$ & $\begin{array}{c}0.003 \\
(0.002)\end{array}$ & $\begin{array}{l}0.007^{*} \\
(0.004)\end{array}$ \\
\hline dec_10(ret) & $\begin{array}{l}0.003 \\
(0.003)\end{array}$ & $\begin{array}{l}0.003 \\
(0.004)\end{array}$ & $\begin{array}{l}0.003 \\
(0.004)\end{array}$ & $\begin{array}{c}0.005 \\
(0.004)\end{array}$ & $\begin{array}{c}0.006 \\
(0.006)\end{array}$ \\
\hline dec_1(ret) x LO & & $\begin{array}{c}0.012^{* * * *} \\
(0.004)\end{array}$ & $\begin{array}{l}0.010^{* *} \\
(0.004)\end{array}$ & $\begin{array}{c}0.012^{* * *} \\
(0.005)\end{array}$ & $\begin{array}{l}-0.001 \\
(0.005)\end{array}$ \\
\hline dec_2(ret) x LO & & $\begin{array}{c}0.009^{* * *} * \\
(0.003)\end{array}$ & $\begin{array}{c}0.008^{* *} \\
(0.003)\end{array}$ & $\begin{array}{c}0.005^{*} \\
(0.003)\end{array}$ & $\begin{array}{l}-0.000 \\
(0.004)\end{array}$ \\
\hline dec_3(ret) x LO & & $\begin{array}{c}0.005 \\
(0.003)\end{array}$ & $\begin{array}{c}0.003 \\
(0.003)\end{array}$ & $\begin{array}{l}0.005^{*} \\
(0.003)\end{array}$ & $\begin{array}{l}-0.003 \\
(0.003)\end{array}$ \\
\hline dec_1(ret) x HI & & $\begin{array}{c}0.011^{* *} \\
(0.004)\end{array}$ & $\begin{array}{l}0.001 \\
(0.005)\end{array}$ & $\begin{array}{c}0.003 \\
(0.005)\end{array}$ & $\begin{array}{l}-0.002 \\
(0.010)\end{array}$ \\
\hline dec_2(ret) x HI & & $\begin{array}{c}0.003 \\
(0.003)\end{array}$ & $\begin{array}{c}0.003 \\
(0.003)\end{array}$ & $\begin{array}{l}-0.004 \\
(0.003)\end{array}$ & $\begin{array}{l}-0.001 \\
(0.006)\end{array}$ \\
\hline dec_3(ret) x HI & & $\begin{array}{c}0.002 \\
(0.002)\end{array}$ & $\begin{array}{c}0.001 \\
(0.002)\end{array}$ & $\begin{array}{l}-0.003 \\
(0.002)\end{array}$ & $\begin{array}{l}-0.001 \\
(0.005)\end{array}$ \\
\hline dec_8(ret) x LO & & $\begin{array}{c}0.000 \\
(0.003)\end{array}$ & $\begin{array}{c}0.002 \\
(0.002)\end{array}$ & $\begin{array}{l}-0.001 \\
(0.003)\end{array}$ & $\begin{array}{l}-0.002 \\
(0.003)\end{array}$ \\
\hline dec_9(ret) x LO & & $\begin{array}{c}0.000 \\
(0.003)\end{array}$ & $\begin{array}{c}0.002 \\
(0.004)\end{array}$ & $\begin{array}{l}-0.003 \\
(0.003)\end{array}$ & $\begin{array}{l}-0.006 \\
(0.004)\end{array}$ \\
\hline dec_10(ret) x LO & & $\begin{array}{l}-0.002 \\
(0.005)\end{array}$ & $\begin{array}{l}0.001 \\
(0.005)\end{array}$ & $\begin{array}{l}-0.002 \\
(0.005)\end{array}$ & $\begin{array}{l}-0.004 \\
(0.005)\end{array}$ \\
\hline dec_8(ret) x HI & & $\begin{array}{c}0.002 \\
(0.002)\end{array}$ & $\begin{array}{c}0.002 \\
(0.002)\end{array}$ & $\begin{array}{l}-0.003 \\
(0.002)\end{array}$ & $\begin{array}{l}-0.003 \\
(0.005)\end{array}$ \\
\hline dec_9(ret) x HI & & $\begin{array}{c}0.002 \\
(0.003)\end{array}$ & $\begin{array}{l}-0.004 \\
(0.003)\end{array}$ & $\begin{array}{l}-0.003 \\
(0.003)\end{array}$ & $\begin{array}{l}-0.004 \\
(0.005)\end{array}$ \\
\hline dec_10(ret) x HI & & $\begin{array}{c}0.002 \\
(0.006)\end{array}$ & $\begin{array}{l}-0.003 \\
(0.005)\end{array}$ & $\begin{array}{l}-0.004 \\
(0.004)\end{array}$ & $\begin{array}{l}-0.000 \\
(0.010)\end{array}$ \\
\hline LO & & $\begin{array}{l}0.001 \\
(0.002)\end{array}$ & $\begin{array}{c}0.004 \\
(0.003)\end{array}$ & $\begin{array}{l}-0.003 \\
(0.003)\end{array}$ & $\begin{array}{l}-0.003 \\
(0.002)\end{array}$ \\
\hline $\mathrm{HI}$ & & $\begin{array}{l}-0.001 \\
(0.002)\end{array}$ & $\begin{array}{c}-0.004^{*} \\
(0.002)\end{array}$ & $\begin{array}{l}0.000 \\
(0.002)\end{array}$ & $\begin{array}{c}0.001 \\
(0.003)\end{array}$ \\
\hline $\begin{array}{l}\text { Time Fixed Effects } \\
\text { Controls }\end{array}$ & $\begin{array}{l}\text { Yes } \\
\text { Yes }\end{array}$ & $\begin{array}{l}\text { Yes } \\
\text { Yes }\end{array}$ & $\begin{array}{l}\text { Yes } \\
\text { Yes }\end{array}$ & $\begin{array}{l}\text { Yes } \\
\text { Yes }\end{array}$ & $\begin{array}{l}\text { Yes } \\
\text { Yes }\end{array}$ \\
\hline $\begin{array}{l}\text { Observations } \\
\text { Adjusted R-squared }\end{array}$ & $\begin{array}{c}108,524 \\
0.073\end{array}$ & $\begin{array}{c}108,524 \\
0.074\end{array}$ & $\begin{array}{c}108,524 \\
0.074\end{array}$ & $\begin{array}{c}108,524 \\
0.074\end{array}$ & $\begin{array}{c}101,098 \\
0.075\end{array}$ \\
\hline
\end{tabular}




\section{Table 7}

\section{Other Forms of Segmentation: Retail v. Institutional Funds; and Brokered v.}

Directly-Sold Funds

The table reports the estimated coefficients of monthly regressions of fund annual performance on past annual performance and selected fund characteristics in the 1996-2010 period. Risk-adjusted performance is estimated using Carhart's (1997) four-factor model. $\alpha$ denotes performance over the prior 12 months. dec_n is a dummy variable that equals one if the fund belongs to the $n$-th decile of the monthly distribution of past performance. Coefficients for control variables are not reported. Controls include: size, flow, age, family size, family age, front-end and back-end loads, and portfolio turnover, as defined in Table 3. Regressors include month dummies. Each regression is run on a different sample: All funds (Column 1); Retail funds (Column 2); Institutional funds (Column 3); Brokered funds (Column 4); and Directly sold (Column 5). Standard errors are clustered by both fund and month. ***, **, and * indicate significance at the $1 \%, 5 \%$, and $10 \%$ levels, respectively

\begin{tabular}{lccccc}
\hline & $(1)$ & $(2)$ & $(3)$ & $(4)$ & $(5)$ \\
& All & Retail & Instit. & Broker & Direct \\
\hline dec_1 $(\alpha)$ (bottom $)$ & $-0.008^{* * *}$ & $-0.008^{* * * *}$ & $-0.009^{* *}$ & $-0.007^{* *}$ & $-0.010^{* * *}$ \\
& $(0.002)$ & $(0.003)$ & $(0.004)$ & $(0.003)$ & $(0.003)$ \\
dec_2 $(\alpha)$ & $-0.004^{* * *}$ & $-0.004^{* * *}$ & -0.003 & $-0.005^{* * *}$ & -0.003 \\
& $(0.001)$ & $(0.002)$ & $(0.002)$ & $(0.002)$ & $(0.002)$ \\
dec_3 $(\alpha)$ & $-0.003^{* * *}$ & $-0.003^{* * *}$ & -0.000 & $-0.005^{* * *}$ & -0.000 \\
& $(0.001)$ & $(0.001)$ & $(0.002)$ & $(0.001)$ & $(0.001)$ \\
dec_8 $(\alpha)$ & $0.003^{* * *}$ & $0.003^{* * *}$ & 0.001 & $0.004^{* * *}$ & 0.002 \\
& $(0.001)$ & $(0.001)$ & $(0.002)$ & $(0.001)$ & $(0.001)$ \\
dec_9 $(\alpha)$ & $0.006^{* * *}$ & $0.006^{* * *}$ & $0.008^{* * *}$ & $0.007^{* * *}$ & $0.006^{* * *}$ \\
& $(0.002)$ & $(0.002)$ & $(0.003)$ & $(0.002)$ & $(0.002)$ \\
dec_10 $(\alpha)$ (top) & $0.010^{* * *}$ & $0.009^{* * *}$ & $0.014^{* *}$ & $0.012^{* * *}$ & $0.007^{* *}$ \\
& $(0.003)$ & $(0.003)$ & $(0.006)$ & $(0.004)$ & $(0.004)$ \\
Time Fixed Effects & Yes & Yes & Yes & Yes & Yes \\
Controls & Yes & Yes & Yes & Yes & Yes \\
Observations & 108,524 & 86,599 & 21,925 & 51,978 & 56,546 \\
Adjusted R-squared & 0.076 & 0.077 & 0.099 & 0.092 & 0.065 \\
\hline
\end{tabular}


Table 8

Fund Visibility and Total Annual Fees (1-Year Holding Period)

The table reports the estimated coefficients of annual regressions of total annual fees on past visibility dummies and selected fund characteristics in the 1996-2010 period. Total annual fee is computed as the sum of the expense ratio and annualized loads, assuming a 1-year holding period, and expressed in percent units. Controls include: size, age, family size, family age, portfolio turnover, annual return volatility, and Carhart's (1997) risk-adjusted performance over the prior three years (annualized and expressed in percent units). All controls are lagged one year. Regressions also include dummy variables for months and investment categories. HI is a dummy variable that equals one if the fund belongs to the top quartile of the monthly distribution of: the number of investment categories in the family (column 1); family size (column 2); family age (column 3); or family advertising (column 4). LO is defined analogously for the bottom quartile, except in column 4 where it equals one if the fund's family has no reported advertising expenditures. Standard errors are clustered by both fund and month. ***, **, and * indicate significance at the $1 \%, 5 \%$, and $10 \%$ levels, respectively

\begin{tabular}{|c|c|c|c|c|}
\hline & $\begin{array}{c}(1) \\
\text { \#Inv Cat }\end{array}$ & $\begin{array}{c}(2) \\
\text { Family Size }\end{array}$ & $\begin{array}{c}(3) \\
\text { Family Age }\end{array}$ & $\begin{array}{c}(4) \\
\text { Family Adv. }\end{array}$ \\
\hline $\mathrm{LO}$ & $\begin{array}{c}-0.923^{* * *} \\
(0.155)\end{array}$ & $\begin{array}{c}-0.851^{* * *} \\
(0.246)\end{array}$ & $\begin{array}{c}-0.290^{* *} \\
(0.138)\end{array}$ & $\begin{array}{c}0.494^{* * *} \\
(0.160)\end{array}$ \\
\hline HI & $\begin{array}{c}-0.296^{*} \\
(0.174)\end{array}$ & $\begin{array}{l}-0.110 \\
(0.188)\end{array}$ & $\begin{array}{c}0.220 \\
(0.195)\end{array}$ & $\begin{array}{c}-0.767^{* * *} \\
(0.280)\end{array}$ \\
\hline size & $\begin{array}{l}-0.029 \\
(0.047)\end{array}$ & $\begin{array}{l}-0.064 \\
(0.046)\end{array}$ & $\begin{array}{l}-0.060 \\
(0.046)\end{array}$ & $\begin{array}{l}-0.069 \\
(0.047)\end{array}$ \\
\hline age & $\begin{array}{c}0.323^{* *} \\
(0.126)\end{array}$ & $\begin{array}{c}0.345^{* * * *} \\
(0.128)\end{array}$ & $\begin{array}{c}0.333^{* * *} \\
(0.127)\end{array}$ & $\begin{array}{c}0.348^{* * *} \\
(0.125)\end{array}$ \\
\hline turnover & $\begin{array}{c}0.016 \\
(0.084)\end{array}$ & $\begin{array}{l}-0.003 \\
(0.087)\end{array}$ & $\begin{array}{c}0.022 \\
(0.086)\end{array}$ & $\begin{array}{l}-0.009 \\
(0.091)\end{array}$ \\
\hline fam_size & $\begin{array}{l}-0.044 \\
(0.047)\end{array}$ & $\begin{array}{l}-0.068 \\
(0.067)\end{array}$ & $\begin{array}{c}0.020 \\
(0.039)\end{array}$ & $\begin{array}{c}0.086^{* *} \\
(0.044)\end{array}$ \\
\hline fam_age & $\begin{array}{c}1.080^{* * * *} \\
(0.106)\end{array}$ & $\begin{array}{c}1.082^{* * * *} \\
(0.109)\end{array}$ & $\begin{array}{c}0.886^{* * *} \\
(0.156)\end{array}$ & $\begin{array}{c}1.088^{* * *} \\
(0.111)\end{array}$ \\
\hline volatility & $\begin{array}{c}4.374 \\
(2.827)\end{array}$ & $\begin{array}{c}4.233 \\
(2.853)\end{array}$ & $\begin{array}{c}4.050 \\
(2.938)\end{array}$ & $\begin{array}{c}5.485^{* *} \\
(2.545)\end{array}$ \\
\hline performance & $\begin{array}{c}-0.029 * * * \\
(0.009)\end{array}$ & $\begin{array}{c}-0.033^{* * *} \\
(0.009)\end{array}$ & $\begin{array}{c}-0.032^{* * *} \\
(0.009)\end{array}$ & $\begin{array}{c}-0.032^{* * *} \\
(0.010)\end{array}$ \\
\hline Constant & $\begin{array}{c}-3.794^{* * *} \\
(0.827)\end{array}$ & $\begin{array}{c}-3.760^{* * *} \\
(0.903)\end{array}$ & $\begin{array}{c}-3.204^{* * *} \\
(1.129)\end{array}$ & $\begin{array}{c}-5.875^{* * *} \\
(0.752)\end{array}$ \\
\hline Time Fixed Effects & $\begin{array}{l}\text { Yes } \\
\text { Yes }\end{array}$ & $\begin{array}{l}\text { Yes } \\
\text { Yes }\end{array}$ & $\begin{array}{l}\text { Yes } \\
\text { Yes }\end{array}$ & $\begin{array}{l}\text { Yes } \\
\text { Yes }\end{array}$ \\
\hline $\begin{array}{l}\text { Observations } \\
\text { Adjusted R-squared }\end{array}$ & $\begin{array}{l}9,370 \\
0.166\end{array}$ & $\begin{array}{l}9,358 \\
0.160\end{array}$ & $\begin{array}{l}9,370 \\
0.151\end{array}$ & $\begin{array}{l}8,372 \\
0.174\end{array}$ \\
\hline
\end{tabular}




\section{Table 9}

Fund Visibility and Total Annual Fees (5-Year Holding Period)

The table reports the estimated coefficients of annual regressions of total annual fees on past visibility dummies and selected fund characteristics in the 1996-2010 period. Total annual fee is computed as the sum of the expense ratio and annualized loads, assuming a 5-year holding period, and expressed in percent units. Controls include: size, age, family size, family age, portfolio turnover, annual return volatility, and Carhart's (1997) risk-adjusted performance over the prior three years (annualized and expressed in percent units). All controls are lagged one year. Regressions also include dummy variables for months and investment categories. HI is a dummy variable that equals one if the fund belongs to the top quartile of the monthly distribution of: the number of investment categories in the family (column 1); family size (column 2); family age (column 3); or family advertising (column 4). LO is defined analogously for the bottom quartile, except in column 4 where it equals one if the fund's family has no reported advertising expenditures. Standard errors are clustered by both fund and month. ***, **, and * indicate significance at the $1 \%, 5 \%$, and $10 \%$ levels, respectively

\begin{tabular}{|c|c|c|c|c|}
\hline & \#Inv Cat & Family Size & Family Age & Family Adv. \\
\hline $\mathrm{LO}$ & $\begin{array}{c}-0.213^{* * *} \\
(0.043)\end{array}$ & $\begin{array}{c}-0.275^{* * * * *} \\
(0.061)\end{array}$ & $\begin{array}{c}-0.113^{* * *} \\
(0.040)\end{array}$ & $\begin{array}{c}0.121^{* *} \\
(0.047)\end{array}$ \\
\hline $\mathrm{HI}$ & $\begin{array}{l}-0.059 \\
(0.048)\end{array}$ & $\begin{array}{c}0.008 \\
(0.053)\end{array}$ & $\begin{array}{c}0.065 \\
(0.052)\end{array}$ & $\begin{array}{c}-0.205^{* * *} \\
(0.079)\end{array}$ \\
\hline size & $\begin{array}{c}-0.027^{* *} \\
(0.013)\end{array}$ & $\begin{array}{c}-0.035^{* * *} \\
(0.013)\end{array}$ & $\begin{array}{c}-0.034^{* * *} \\
(0.013)\end{array}$ & $\begin{array}{c}-0.035^{* * *} \\
(0.013)\end{array}$ \\
\hline age & $\begin{array}{c}0.010 \\
(0.035)\end{array}$ & $\begin{array}{c}0.017 \\
(0.035)\end{array}$ & $\begin{array}{c}0.012 \\
(0.035)\end{array}$ & $\begin{array}{c}0.014 \\
(0.034)\end{array}$ \\
\hline turnover & $\begin{array}{l}0.038^{*} \\
(0.023)\end{array}$ & $\begin{array}{c}0.033 \\
(0.023)\end{array}$ & $\begin{array}{l}0.039^{*} \\
(0.023)\end{array}$ & $\begin{array}{c}0.032 \\
(0.025)\end{array}$ \\
\hline fam_size & $\begin{array}{c}-0.050^{* * *} \\
(0.014)\end{array}$ & $\begin{array}{c}-0.070^{* * *} \\
(0.018)\end{array}$ & $\begin{array}{c}-0.036^{* * *} \\
(0.011)\end{array}$ & $\begin{array}{l}-0.019 \\
(0.012)\end{array}$ \\
\hline fam_age & $\begin{array}{c}0.329^{* * *} * \\
(0.033)\end{array}$ & $\begin{array}{c}0.328^{* * * *} \\
(0.033)\end{array}$ & $\begin{array}{c}0.262^{* * * *} \\
(0.045)\end{array}$ & $\begin{array}{c}0.334^{* * * *} \\
(0.034)\end{array}$ \\
\hline volatility & $\begin{array}{c}2.702^{* * * *} \\
(0.868)\end{array}$ & $\begin{array}{c}2.677^{* * *} \\
(0.856)\end{array}$ & $\begin{array}{c}2.607^{* * * *} \\
(0.897)\end{array}$ & $\begin{array}{c}3.072^{* * * *} \\
(0.852)\end{array}$ \\
\hline performance & $\begin{array}{c}-0.011^{* * *} \\
(0.003)\end{array}$ & $\begin{array}{c}-0.012^{* * *} \\
(0.003)\end{array}$ & $\begin{array}{c}-0.012^{* * *} \\
(0.003)\end{array}$ & $\begin{array}{c}-0.012^{* * *} \\
(0.004)\end{array}$ \\
\hline Constant & $\begin{array}{c}0.300 \\
(0.230)\end{array}$ & $\begin{array}{c}0.400^{*} \\
(0.235)\end{array}$ & $\begin{array}{l}0.567^{*} \\
(0.311)\end{array}$ & $\begin{array}{l}-0.277 \\
(0.208)\end{array}$ \\
\hline Time Fixed Effects & Yes & Yes & Yes & Yes \\
\hline Inv. Cat. Fixed Effects & Yes & Yes & Yes & Yes \\
\hline $\begin{array}{l}\text { Observations } \\
\text { Adjusted R-squared }\end{array}$ & $\begin{array}{l}9,370 \\
0.144\end{array}$ & $\begin{array}{l}9,358 \\
0.145\end{array}$ & $\begin{array}{l}9,370 \\
0.135\end{array}$ & $\begin{array}{l}8,372 \\
0.153\end{array}$ \\
\hline
\end{tabular}

